\title{
Al-Bashir didn't start the fire. Diversity, low contestedness, and the adoption of the Rome Statute of the International Criminal Court
}

\author{
Lucrecia García Iommi
}

Follow this and additional works at: https://digitalcommons.fairfield.edu/politics-facultypubs

Copyright (C) 2020 Taylor \& Francis

This is an Accepted Manuscript of an article published by Taylor \& Francis in Cambridge Review of International Affairs on 23/4/2020, available online: http://www.tandfonline.com/10.1080/ 09557571.2020 .1751070$.

\section{Peer Reviewed}

\section{Published Citation}

García lommi, Lucrecia. "Al-Bashir didn't start the fire. Diversity, low contestedness, and the adoption of the Rome Statute of the International Criminal Court." Cambridge Review of International Affairs (2020): 1-32. DOI: 10.1080/ 09557571.2020.1751070

This item has been accepted for inclusion in DigitalCommons@Fairfield by an authorized administrator of DigitalCommons@Fairfield. It is brought to you by DigitalCommons@Fairfield with permission from the rightsholder(s) and is protected by copyright and/or related rights. You are free to use this item in any way that is permitted by the copyright and related rights legislation that applies to your use. For other uses, you need to obtain permission from the rights-holder(s) directly, unless additional rights are indicated by a Creative Commons license in the record and/or on the work itself. For more information, please contact digitalcommons@fairfield.edu. 


\title{
Al-Bashir Didn't Start the Fire. Diversity, Low Contestedness, and the Adoption of the Rome Statute of the International Criminal Court
}

\author{
Lucrecia García Iommi, PhD
}

This paper contends that despite it functioning as a catalyst, the ICC "Africa problem" did not start with the arrest warrant against al-Bashir. To fully comprehend the current legitimacy crisis we must understand the nature of the negotiation process that led to the adoption of the Rome Statute and its enduring impact. In particular, we must acknowledge the uneven ability of states to formulate and signify their preferences on the basis of their identity and interests during the negotiation process. Drawing from Wiener's theory of contestation, the paper contends that the absence of meaningful engagement with issues germane to some ICC stakeholders before and during the Rome Conference facilitated the adoption of the Rome Statute, but also plausibly created difficulties for the Court in the long run. Specifically, it postponed unavoidable conflict over contentious issues and undermined the likelihood that specific stakeholders would develop a sense of ownership over the Statute.

\section{Introduction}

Since its inception, the International Criminal Court (the ICC or the Court) has faced considerable challenges. In recent years, scholars have focused their attention on the Court's legitimacy problem, in particular vis-à-vis its African stakeholders (Arcudi 2019; García Iommi 2019). ${ }^{1}$ In particular, they have highlighted the negative impact that the arrest warrant against Omar al-Bashir has had on the ICC's standing in the region and how it has fostered contestation (Mills 2012; Mills and Bloomfield 2018; Boehme 2017). In 2009, the Court issued an arrest warrant against al-Bashir for crimes against humanity and war crimes. Concerned with the repercussions of targeting a sitting head of state in a context of on-going conflict, some African states galvanized their African Union (AU) peers into resistance (Mills and Bloomfield 2018, 108). This paper contends that despite functioning as a catalyst, the ICC's "Africa problem" did not start with al-Bashir's arrest warrant. To fully comprehend the current legitimacy crisis we must understand the nature of the negotiation process that led to the adoption of the Rome Statute for an International Criminal Court (the Rome Statute or the Statute) and its enduring impact. In particular, we must acknowledge the uneven ability of states to formulate and signify

\footnotetext{
${ }^{1}$ This is surprising considering that African countries were amongst the first to ratify the Rome Statute and thus critical its entry into force in 2002. They constitute the largest regional block of ICC member states with thirty-three members (Assembly of States Parties to the Rome Statute website). Yet in the past few years, Gambia, South Africa, Namibia, and Kenya announced plans to withdraw from the ICC and Burundi exited in 2017.
} 
their preferences during the negotiation process and how it shaped the negotiation itself, its outcome, and the present of the Court.

This paper contends that identity and interests shaped states' preferences towards the creation of a strong and independent court as embodied in the Statute. ${ }^{2}$ Specifically, this paper finds that "Western-ness", as a dimension of state identity, is a strong predictor for support for the Rome Statute. This dimension of identity embodies a specific vision of justice that the prevalent liberal understanding of justice in international criminal law (Fichtelberg 2006) mirrors. Simultaneously, participation in militarized interstate disputes and US assistance negatively influenced states' support for the Rome Statute. Because involvement in militarized conflict increases the likelihood of the ICC investigating a country's nationals, states in that situation perceived support for a strong and independent court as detrimental to their sovereignty and were less likely to support it. Similarly, the opposition of the United States to the Statute explains that countries benefiting from US assistance would be less likely to support the Rome Statute.

This paper further explains that states that scored highly in these variables were likely to enter the negotiation with clear preferences and to act as advocates or detractors of a strong and an independent court. However, most states scored moderate values across said variables. Accordingly they did not start the negotiation with clear preferences. Instead they developed these preferences later in the negotiation. Indeed, many of these states did not manifest, and plausibly had not yet developed, clear preferences regarding what kind of court they would endorse until the end of the process.

In relation to this, this paper argues that for numerous states the lack of resources limited the extent and quality of their participation in the negotiations before and during the Rome Conference. This negatively affected their ability to formulate and signify their preferences early on and autonomously. ${ }^{3}$ Indeed, small states ${ }^{4}$ could not participate in negotiations with the same frequency their wealthier counterparts did nor did they enjoy comparable technical expertise. As a result, the impact of identity on support for the Rome Statute was considerably weaker for poor states. Without a doubt, there were states, including several smaller states from the Global South, that were fully committed to creating a strong an independent court from the get-go and they skilfully worked to realize this goal as part of a coalition of like-minded states (Deitelhoff and Wallbott 2012; Panke 2012). However, a majority of the small states that eventually supported the adoption of the Rome Statute were never its advocates. Instead, they were persuaded to support the adoption of the Statute during the negotiation.

\footnotetext{
${ }^{2}$ A strong and independent court refers to a court that is independent from the United Nations Security Council (UNSC), has inherent jurisdiction and a prosecutor with propio motu powers. ${ }^{3}$ This is not to say that individual, small states did not articulate any preferences. The Caribbean states, for example, fiercely advocated for the inclusion of transnational drug crimes (Robinson 2002).

${ }^{4}$ The model defines small/ poor states as those with (natural logarithm) of GDP below 24 in 1998. Slovenia, Sri Lanka and Ecuador are all examples of countries in this category.
} 
The impact of wealth on states' ability to formulate and signify their preferences helps us understand the conditions that made persuasion, a well-established mechanism in the adoption of the Rome Statute (Struett 2008; Deitelhoff, 2009), possible in the first place. Indeed, the absence of clear preferences made it possible for advocates of a strong and independent court to persuade a majority of states to do so as well. This is not to say that these advocates, predominantly the Like-Minded Group (LMG) and the Coalition for an International Criminal Court (CICC), ${ }^{5}$ convinced only countries with undefined preferences. However, the large number of undecided states facilitated the effort of persuading enough states to secure the adoption of the Rome Statute.

This insight is also relevant in relation to the enduring consequences of the negotiation on the legitimacy of the ICC. Indeed, the negotiation was limited around some issues, such as the use of amnesties, which would later on prove critical for some stakeholders. Thus, while persuasion ensured the adoption of the Rome Statute, it also created substantial problems down the line. As norm entrepreneurs usually do, advocates of a strong and independent court primarily relied on framing, education, lobbing, and shaming. Accordingly there was limited open-ended discussion. Furthermore, meaningful exchanges were exceedingly difficult because of the asymmetry of resources between participants. While the negotiation succeeded, limited contestation in the negotiation stage plausibly only delayed inevitable clashes between actors from different backgrounds over the Statute.

Drawing from Wiener's theory of contestation (2014), this paper argues that a more inclusive process where all stakeholders had regular and institutionalized access to contestation (contestedness) in the negotiations leading to the Rome Conference and during the Conference would have preempted and perhaps mitigated contestation today. Furthermore, the significant role that the CICC played in the adoption of the Rome Statute and in its entry into force legitimized their efforts to expand their role as advocates of the Statute (Haddad 2013, 189). In the process, these actors positioned themselves as authoritative interpreters of what constitutes the proper implementation of the Rome Statute in light of the anti-impunity norm its embodies (Engle 2015). In this role, they have precluded meaningful dialogue on the proper interpretation of the Statute, deeming challenges to their own interpretation as misguided at best and, at worst, as attempts to "water down" the anti-impunity norm (García Iommi 2019).

This paper thus contributes to the literature in three ways. First, it furthers our understanding of the adoption of the Rome Statute by identifying the role that state identity and interests played in the process. It also outlines the conditions that made it possible to persuade a majority of the international community to adopt the Statute, emphasizing the role of the LMG in the process. In this way, it complements the literature's predominant focus on the role that civil society played in the negotiation (Glasius 2002 \& 2005; Leonard 2005). Finally, this paper

\footnotetext{
${ }^{5}$ The LMG was an informal alliance of diverse states from around the world that shared a commitment to establishing an effective international criminal court. It grew from a dozen founding states to around 60 states by the beginning of the Rome Conference (Bassiouni, 1999). The CICC is an umbrella organization that coordinated the efforts of hundreds of NGOs during the negotiation and continued to advocate for the ratification of the Rome Statute and for cooperation with the Court (CICC website).
} 
explains how the origins of the current ICC legitimacy crisis can be traced back to the negotiation of the Rome Statute both in terms of delaying inevitable clashes and in relation to the current status of the LMG and the CICC as "keepers" of the Statute.

The rest of the paper is organized in four sections. The first section addresses existing explanations for the adoption of the Rome Statute and situates this paper's contributions in that context. Drawing from Wiener's theory of contestation, this section also addresses the long-term consequences of limited access to contestation for small states in the negotiation stage. The second section outlines the hypotheses that guide the empirical analysis, which the third section discusses. The third section combines quantitative and qualitative evidence in support of the argument. The conclusion discusses the findings in light of the current challenges the ICC faces and its implications for future negotiations.

\section{The ICC and its origins}

The ICC is a permanent, treaty-based international criminal court, established to guarantee that the core crimes under international law (genocide, crimes against humanity, war crimes and aggression) do not go unpunished. The negotiation of the Rome Statute started in 1995 in the Ad Hoc Committee. ${ }^{6}$ Between 1996 and 1998, six sessions of the UN Preparatory Committee continued these negotiations with the purpose of elaborating a draft statute. ${ }^{7}$ From June $15^{\text {th }}$ to July $17^{\text {th }} 1998$ the United Nations Diplomatic Conference of Plenipotentiaries on the Establishment of an International Criminal Court (the Rome Conference or the Conference) brought together the representatives of over 150 governments and hundreds of NGOs. Defying the expectations of scholars and practitioners alike, the delegates drafted and eventually adopted the Rome Statute. In the final vote, 120 states voted in favor of the Statute, twenty-one abstained, and seven states, including the USA, Israel and China, voted against it.

There are multiple explanations of the creation of the ICC. The creation of the Court entails a first constitutive moment, the preparatory work, negotiation, and adoption of the Rome Statute, and a second stage, the entry into force of the Statute. From a rationalist perspective, scholars have emphasized domestic political incentives to support the ICC (Simmons and Danner 2010; Powell and McLaughlin 2011), the effects of economic interdependence (Goodliffe and Hawkins 2009) as well as the idea that a permanent international criminal court would be more cost-effective than the ad hoc tribunals (Fehl 2004). Nevertheless, it is accounts focused on ideational factors that have dominated the discussion of the first stage of the process. In this literature, some scholars understand the creation of the ICC as a response to an increasing global demand for justice and the protection of human rights (Broomhall 2003; Leonard 2005). Other scholars emphasize the role of civil society organizations. Specifically, they contend that NGOs played a critical role in fostering innovations, such as the incorporations of victims' rights and

\footnotetext{
${ }^{6}$ In 1994, the ICC Statute was discussed in the General Assembly's Sixth Committee. The United Nations International Law Commission had produced a first draft that year.

${ }^{7}$ Negotiations continued after the Rome Conference in the Preparatory Commission. These negotiations produced the ICC's Rules of Procedure and Evidence.
} 
gender crimes (Glasius 2002, 142; 2005) and, more significantly, in persuading states to support the creation of a strong and independent court (Struett 2008, 129). The narrative that emerges from this literature is that civil society organizations successfully persuaded states to support such a court in spite of their preexisting preference for the protection of their sovereignty (Struett, 2008: 6). In some accounts, the LMG states also played a critical role in gathering support for the Rome Statute (Deitelhoff 2009). These explanations, which remain very influential in the literature on the first stage of the creation of the ICC, do not sufficiently address the underlining conditions that made persuasion possible in the first place. Furthermore, they afford surprisingly little attention to identity and how it shaped states' preferences. ${ }^{8}$

Constructivists have long established the significance of state identity in relation to states' interests and behaviour (Wendt 1999; Katzenstein 1996; Risse-Kappen 1995; Barnett 2002; Ashizawa 2008). However, many Constructivist scholars favour linear and progressive narratives of norm diffusion that emphasize convergence, underestimating and even delegitimizing local resistance (Acharya 2004, 242). In these arguments, it is often the case that enlightened transnational (Western) elites educate backwards states on the "right" norms to follow (Epstein 2012). These narratives downplay the role that the enduring differences between states and states' identities play on norm dynamics. In response, a second wave of Constructivist scholarship emphasizes national and regional differences (Acharya 2004 \& 2013; Wiener 2008). From their perspective, the constructive engagement of all stakeholders with the norms that govern them is critical to their legitimacy and structuring power (Wiener 2014).

\section{Wiener's theory of contestation and the ICC}

Wiener argues that the meaning of norms only becomes apparent in context (meaning-inuse) and that in a world of enduring cultural differences ${ }^{9}$ contestation over specific norms is bound to take place (Wiener 2008; 2014; 2009, 175-193). Indeed, cultural differences often generate distinct interpretations of norms amongst stakeholders, shaping their behavior accordingly (Wiener 2014, 45, 48). While contestation can undermine a norm's legitimacy, it can also strengthen it. Indeed, contestation is indispensable for diverse actors to accept a norm. Specifically, stakeholders' engagement fosters norm "ownership", which increases their perception that the norm embodies a standard of appropriateness (Park and Vetterlein in Wiener 2016, 22). Whether clashes over the proper interpretation and implementation of a norm culminate in conflict or lead to compromise depends on how actors conduct their encounters (Wiener 2017a, 114). Because agreement over the meaning-in-use of norms is unlikely to emerge on its own (Wiener and Puetter 2009, 2) and because this agreement is necessary for

\footnotetext{
${ }^{8}$ It is worth mentioning other significant contributions, which approach the creation of the ICC from a diplomatic history perspective (Bassiouni 1999; Benedetti and Washburn 1999; Benedetti et al. 2013).

${ }^{9}$ Wiener's understanding of culture involves recognizing common national and regional "background experiences" derived from historical interactions and expressed through everyday practices of normative validation (Wiener 2014, 45). Therefore, it can accommodate ideational and material variables.
} 
norms to gain validity (Wiener 2014, 30), facilitating access to contestation for stakeholders is necessary for fair and effective global governance (Wiener 2014, 3). Without it, norms cannot become legitimate because divergent interpretations will arise, remain unresolved, and lead to conflict.

There is another feature of Wiener's theory of contestation that is relevant to this paper. While all norms are subject to contestation, stakeholder's access to contestation and thus the likelihood of contestation vary across the constituting, referring, and implementing stages of the norm cycle (Wiener 2014, 19, 21). Furthermore, Wiener argues that specific dimensions of norm validity are more likely to be contested in some of these stages than in others (Wiener 2014, 2930). The formal validity of a norm refers to the framework of reference for interpreting and implementing norms created by legal language and it is most likely to be questioned at the constituting stage, when a political community institutionalizes the norm. In turn, a norm's social recognition encompasses social interactions enacting specific meanings of a norm and it is most likely to be contested at the referring stage when the norm is invoked as an indicator of appropriate behaviour. Finally, cultural validation refers to the contextualized meaning norms acquire across different cultures. It is highly contested at the implementation stage, when individual norm-users with different background experiences enact the norm.

Wiener's theory thus establishes the significance of access to contestation at every stage of the norm cycle. The next step in her theory is to elucidate what access to (regular and institutionalized) contestation (contestedness) for all stakeholders in all stages of norm implementation with reference to all forms of norm validation would look like. Wiener identifies proactive contestation as the critical indicator of contestedness. Specifically, she argues that to assess access to contestation, we must evaluate the degree to which stakeholders are free to implement or reject a norm (reactive contestation), but even more fundamentally to change the meaning of the norm "through purposeful and normative "pro-action" (proactive contestation) (Wiener 2017b, 7).

Applied to the case of the ICC, Wiener's arguments can help us understand the Court's current legitimacy crisis. Focusing on the implementing stage of the anti-impunity norm as embodied in the Rome Statute, I have explained that the absence of access to contestation for African stakeholders contributed to the Court's "Africa Problem" (2019). Specifically, low contestedness turned predictable contestation over the cultural validation of said norm at the implementation stage into conflict. Other scholars have also focused on contestation at the implementation stage (Mills and Bloomfield 2018; Bower 2019). In contrast, this paper focuses on the negotiation of the Rome Statute and the negative impact that limited resources had on numerous states' ability to formulate and signify their preferences. This led to restricted proactive contestation in the negotiation process, which in the short term facilitated the adoption of the Rome Statute, but in the long-term compromised the legitimacy of the Court. Indeed, it left critical issues regarding the legal framework of the Court unresolved. It also undermined the possibility of all stakeholders developing a sense of ownership over the Rome Statute because so many of them did not fully participate in its design. 


\section{Model, Method and Operationalization}

Focusing on the constitutive stage of the Rome Statute, my model explains that state identity determined varying levels of support for the Rome Statute. In addition to this, it anticipates that due to the nature of the crimes under the jurisdiction of the Court, (actual and potential) involvement in militarized conflict negatively affected support for a strong and independent court. In contrast, countries that scored moderate values in the relevant variables did not have strong preferences and could be more easily persuaded to adopt specific positions. In relation to persuasion, the model establishes that lack of resources negatively impacted states' ability to formulate and signify their preferences during the negotiation process, creating ideal conditions for persuasion to take place.

Assessing states' preferences towards the Rome Statute constitutes a challenge. ${ }^{10}$ First, there is limited information on states' positions because there are no official records of the negotiations during the PrepComs or of the final vote in the Rome Conference (Bennedetti and Washburn 1999, 34, note 2). ${ }^{11}$ Second, the information that does exist in the form of states' official statements is not sufficient to infer actual positions and to differentiate among states' positions (Bennedetti and Washburn 1999, 29). For instance, LMG states collaborated closely and it was not uncommon for one delegation to bring up an issue on behalf of the group. ${ }^{12}$ Finally, not all states advanced explicit opinions on their preferred outcome throughout the negotiation process. Indeed, around fifty states did not take part in the preparatory committee meetings at all (Pace in Glasius 2002, 140). These limitations make it difficult to operationalize Support for the Rome Statute (dependent variable). As a proxy for states' positions, this paper relies on the data on signatories of the Rome Statute to establish which states supported the

${ }^{10}$ Coding states' support for the ICC based on detailed information on each country's positions throughout the negotiation would be preferable, yet it presents insurmountable difficulties. Consider Goodliffe and Hawkins' work (2009). The authors measure support for the ICC on the basis of official statements made by individual states throughout the negotiation process. To account for numerous "silent" delegations, they code countries that did not express an opinion as neutral. This leads to a conservative bias in their result, which the authors acknowledge (Goodliffe and Hawkins 2009, 985). Alternatively, we could assume continuity and rely on the last position expressed by the state. However, this would be only a partial solution because of the high number of countries that remained uninvolved in the negotiations leading up to Rome.

11 There are statements from states from the preparatory work carried out before the Rome Conference and during the conference. These materials, in addition to the limitations addressed above, are limited because they do not encompass informal meetings and, in the case of the 1995 Ad Hoc Committee, the 1996-1998 Preparatory Committee most of the discussions during the Rome Conference were not recorded as minutes therefore they do not allow us to identify the positions of specific countries (Gissel 2018, 730.)

12 This led states opposed to the ICC to repeatedly protest the non-transparent manner of the LMG (Bennedetti and Washburn 1999, 29). 
adoption of the Statute. ${ }^{13}$ Signatories are presumed to have voted for the Statute and those who are not are assumed to have voted against it or abstained. ${ }^{14}$

To add nuance to the operationalization of the dependent variable the paper utilizes LMG membership, which allows us to distinguish between three levels of support within the universe of states that voted for the Rome Statute. Entrepreneurs (coded 3) encompass the original members of the LMG states, which advocated for a strong, independent court from the beginning of the process. Supporters (coded 2) include those states that joined the LMG as some point during the negotiation process before the Conference. The rest of the states that voted in favor of the adoption of the Rome Statute are the Accepting States (coded 1). While these states did not actively advocate for a strong and independent court, they eventually voted in favor of the Statute. Finally, the states that voted against the Statute or abstained from voting are its Detractors (coded 0).

To define the independent variable, state identity, this paper draws inspiration from Gurowitz's multidimensional conceptualization (1999) ${ }^{15}$ Specifically, it defines states identity along the lines of three dimensions: Proximity to Core, Legalism, and Western-ness. First, our model anticipates that a state's relation with the most powerful country in the world would impact its attitude towards the Rome Statute. Because the United States was strongly opposed to the creation of a strong and independent court, Proximity to Core should have a negative impact on a state's support for the Statute. Legalism, ${ }^{16}$ in turn, refers to a state's reliance on the law as an instrument for the conduct of its foreign affairs. Domestic adherence to the rule of law could be positively correlated with Legalism thus defined, but they remain different variables. Legalism is expected to have a positive impact on support for the Rome Statute because it entails a law-based solution to a specific international problem- that is, international crimes. Finally, selfidentification with the West (Western-ness) ${ }^{17}$ is expected to have a positive impact on support for the Rome Statute. While there are arguably multiple dimensions to Western-ness, for the

\footnotetext{
${ }^{13}$ Signature is a more reliable indicator of support than ratification because the latter entails a stronger commitment and involves diverse internalization processes.

14 This relies on the assumption that states that did not support the Rome Statute (those which voted against the statute or abstained) did not sign the Statute in the aftermath of the Rome Conference. The United States, in many ways an outlier, is the only case that challenges this assumption.

${ }^{15}$ Gurrowitz (1999) defines state identity in terms of four dimensions: 1) self-identification with the centre of the Western society of states, or its periphery, in terms of material and cultural attributes; 2) relation to the dominant power in the international system; 3) commitment to the principle of multilaterialism and 4) extent of activity or passivity in international activities. ${ }^{16}$ Multilateralism and activism fail to capture a preference for the use of legal instruments in the conduct of international affairs, which is critical in relation to the ICC. Accordingly, the paper substitutes multilateralism and activism with Legalism. Legalism incorporates elements of multilateralism and activism, but also embodies a preference for international law as a policy instrument.

${ }^{17}$ It is worth highlighting that in our model, Western-ness refers solely to cultural attributes in an effort to distinguish material and ideational sources of state behaviour.
} 
purposes of this model the focus is on prevailing notions of justice. ${ }^{18}$ The Rome Statute embodies a liberal vision of justice and of law (Bass 2000), ${ }^{19}$ which Western countries have shaped (Chenivesse and Piranio 2011, 406). This conceptualization does not entail an essentialist view of the West, which would allow us to classify countries as Western a priori. On the contrary, Western-ness (a Western view of justice) can be acquired. Accordingly, countries that we do not immediately associate with the West can score high in Western-ness and thus be predicted to exhibit high support for the Rome Statute.

Because Western criminal legal systems recognise punishment as the primary means of dealing with transgressions (Wenzel et al. 2008, 375), punishment is critical to international criminal law. The focus on punishment has deep cultural roots, including the enduring influence of religion (Garland 1990). Indeed, some of the most influential Western thinkers to have addressed the topic of criminal punishment, from Augustine to Kant, were deeply influenced by Christianity (Murphy 2003, 262). Witte and Arthur further explore this connection, explaining that Anglo-American jurists developed the concepts of crime and criminal punishment by drawing upon analogous concepts of sin and divine punishment in the Protestant tradition (1993, 434). The authors consider their understanding of punishment as a means to condemn abhorrent behavior as equally important to the deterrent role of punishment, which is critical to the liberal tradition (Witte and Arthur 1993, 464). This liberal tradition, which above all else emphasizes individual responsibility and the importance of procedural fairness, is also critical to the Western vision of justice (Fichtelberg 2006; Robinson 2013) ${ }^{20}$ From this perspective, the enduring legacies of Christianity and liberalism plausibly impacted states' attitudes towards the Rome Statute in a positive way.

This is not to say that punishment is unique to a Western understanding of justice - nor that pardon is foreign to it (Dean Moore 1989, 15). Punishment exists, for example, in the Islamic tradition. Yet, its retributive function is an extension of its distributive function as a result of its "all-embracing...conception of justice" (Moradian 2006, 402). This distinguishes punishment in this tradition from punishment in the Christian, liberal tradition, which emphasizes the retributive function of punishment and can conceive it, even if that is not always the case, as an end in itself. Tellingly, Kant states "[e]ven in a society were to dissolve itself by common agreement of all of its members...the last murderer remaining in prison must first be executed, so everyone will duly receive what his actions are worth" (in Murphy 1987). This statement perfectly summarizes the centrality of punishment in the Western tradition of justice.

Accordingly, we identify the emphasis on punishment and individual criminal accountability as integral to a Western view of justice, which clashes with other perspectives of

\footnotetext{
${ }^{18}$ Presumably, if the paper addressed other norms, such as support for LGBTQAI rights, it would also operationalize Western-ness in a different manner. This alternative operationalization would emphasize other dimensions of identification with the West critical in relation to that norm, such as pluralism.

${ }^{19}$ However, scholars emphasize how international criminal law often falls short of these aspirations (Vasiliev 2017, 84).

${ }^{20}$ For a critical view on international criminal law's individualism from an African perspective, see Gevers (2014).
} 
justice that privilege reconciliation and social harmony. Archbishop Tutu of South Africa decried the emphasis on punishment and emphasis on retributive justice, stating that "Retributive justice is largely Western. The African understanding is far more restorative- not so much to punish as to redress or restore a balance that has been knocked askew. The justice we hope for is restorative of the dignity of the people" (in Minow 1998, 80). Of course this statement oversimplifies matters, rendering African attitudes homogenous when they are not. Nevertheless, acknowledging persistent cultural differences, as Wiener suggests, is imperative to understand actors' attitudes towards the Rome Statute and the current legitimacy crisis. The non-essentialist characterization of Western-ness used in this paper prevents the reification of culture and allows for intra-regional diversity.

The importance of ideas of justice that emphasize restoration and focus on the society, as opposed to retribution and individual victims and criminals, becomes particularly evident in current clashes in Africa over the proper role of traditional justice mechanisms and the use of amnesties. The use of amnesties, in particular, which African countries have historically relied on to advance peace and reconciliation (Oola 2015, 160) has proved a significant point of contention in the implementation of the Rome Statute (Pensky 2008). Of course, amnesties have been used in countries that ascribe to a Western view of justice. Countries that score relatively high in Western-ness have relied on the use of amnesties in the past. Argentina (2.39/3), Chile (2.67/3), El Salvador (2.18/3), Guatemala (2.23/3), Haiti (1.89/3), Uruguay (2.28/3) and South Africa (2.28/3) have all granted amnesties to individuals who perpetrated international crimes in these countries as part of peace arrangements. This does not invalidate the argument advanced in this paper. Multiple norms as well as material factors influence actors' decisions at any given time. As this paper demonstrates, the United States did not support the Rome Statute in spite of scoring high in Western-ness because of its high involvement in militarized interstate disputes. In this case, interests outweighed the positive impact of identity. The fact remains, as the findings will demonstrate, that a Western view of justice had a positive impact on support for the adoption of the Rome Statute.

To measure these variables the paper relies on a series of proxy indicators. Western-ness is operationalized as a combination of a country's score on liberal democratic values (Freedom House) and on Christian tradition, measured as percentage of the population that self-identifies as Christian. ${ }^{21}$ In addition to this, the paper evaluates the impact of GDP on support for the Rome Statute to ensure that Western-ness captures self-identification with the West and not wealth. Because the US was the most powerful state in the international system in 1998, Proximity to the Core is defined as affinity with the US. The paper operationalizes this variable as voting overlap at the UN General Assembly (Gartzke's Affinity of Nations dataset). While Proximity to Core captures ideological affinity it could potentially obscure dependence on United States economic and military aid. Therefore, we consider the effect of US assistance on the dependent variable as well. In turn, to measure Legalism, the paper relies on the number of bilateral treaties ratified by a state (World Treaty Index). ${ }^{22}$ Finally, the paper relies on data on participation in militarized interstate disputes (MID dataset) and the dummy variable ongoing conflict to measure

\footnotetext{
${ }^{21}$ Both components of the indicator are equally valued.

${ }^{22}$ An alternative measure, the number of universal post-1945 international treaties ratified, led to similar results.
} 
involvement in conflict. The paper also considers military budget as an additional indicator of a country's likelihood to engage in conflict.

The paper tests its hypothesis against well-established alternative arguments. First, it considers the costs and benefits of creating a permanent court vis-à-vis the alternative, that is, continuing to rely on ad hoc tribunals. This echoes the arguments of rationalists on the benefits of creating of international institutions (Keohane 1984; Abbott and Snidal 2000; Koremenos, Lipson, and Snidal 2001), which highlight their role in reducing transaction costs. Accordingly, the more a state financially contributed to ad hoc tribunals the more it would support the creation of the ICC. Alternatively, states could support a strong and independent court in order to lock-in recent commitments to democracy and human rights (Moravcsik 2000). From this perspective, new democracies would be more likely than established ones to support the Rome Statute. Finally, the paper contemplates the possibility of regional effects. Indeed, the literature on human rights and democracy contends that region can be a strong predictor of state behavior (Gleditsch and Ward 2006).

To test the impact of state identity on support for the Rome Statute and assess the validity of alternative explanations the paper relies on ordered logit analysis. The same method establishes that limited resources negatively affected states' ability to realize their preferences, facilitating persuasion. This helped secure a positive outcome for the negotiation, but also fostered lack of access to contestation. To assess this claim, the paper relies on secondary sources, official records, and interviews.

\section{Identity, Interests, and Power in the Adoption of the Rome Statute}

From the 147 states included in the universe of cases, ${ }^{23} 30$ states were Entrepreneurs $(\mathrm{DV}=3), 31$ states were Supporters $(\mathrm{DV}=2)$, 59 states accepted the Rome Statute but never became its advocates ( $D V=1)$, and 27 were Detractors ( $D V=0)^{24}$ (Appendix A). The model appears to be a good predictor of states' support, with most predicted values falling in the correct categories, or one category above or below (Appendix B). The findings demonstrate that Western-ness, US assistance, and Participation in International Militarized Interstate Disputes

\footnotetext{
${ }^{23}$ Only those countries with a population greater than 500,000 people are included. The reason is that micro-states are inherently different (Neumann and Gstohl 2006) and any findings incorporating these cases would be difficult to interpret.

${ }^{24}$ I also ran the model with different versions of the dependent variable: 1) a dichotomic variable (vote for or against the Statute/ Abstention), 2) an ordinal variable with three possible values (LMG states, vote Statute, or vote against the Statute/ Abstention), and an ordinal variable with five possible values (original LMG states, late LMG states, non-LMG states signatories, non signatories that votes against the Statute, non signatories who abstained). This last version relied on secondary sources to make an educated guess regarding who abstained and who voted against the Statute in addition to the United States, China and Israel. The outcomes were extremely similar across all versions.
} 
(PMID) are all relevant explanations of states' support for the ICC $^{25}$. Specifically, Western-ness had a strong positive impact on states support for the ICC, whereas high involvement in militarized inter-state disputes and US assistance had a negative impact (Table I) (Appendix C).

Table I: Model Estimates

\begin{tabular}{|c|c|}
\hline VARIABLES & $\begin{array}{c}(1) \\
\text { Support for Rome Statute }\end{array}$ \\
\hline \multirow[t]{2}{*}{ Western-ness } & $1.420 * * *$ \\
\hline & $(0.327)$ \\
\hline \multirow[t]{2}{*}{ Legalism } & -0.00289 \\
\hline & $(0.00350)$ \\
\hline \multirow[t]{2}{*}{ Proximity to Core } & 0.00945 \\
\hline & $(0.0178)$ \\
\hline \multirow[t]{2}{*}{ Military Budget } & 0.656 \\
\hline & $(0.951)$ \\
\hline \multirow[t]{2}{*}{ GDP } & -0.422 \\
\hline & $(0.937)$ \\
\hline \multirow[t]{2}{*}{ US Assistance } & $-0.0856 * *$ \\
\hline & $(0.0376)$ \\
\hline \multirow[t]{2}{*}{ Contributions to Ad Hoc Tribunals } & -0.0594 \\
\hline & $(0.0597)$ \\
\hline \multirow[t]{2}{*}{ Ongoing Violent Conflict } & -0.0637 \\
\hline & $(0.502)$ \\
\hline \multirow[t]{2}{*}{ Participation in Militarized Interstate Disputes (PMID) } & $-0.0477 * * *$ \\
\hline & $(0.0168)$ \\
\hline \multirow[t]{2}{*}{ Recent Democratization } & 0.283 \\
\hline & $(0.705)$ \\
\hline \multirow[t]{2}{*}{ Asia } & -1.847 \\
\hline & $(0.996)$ \\
\hline \multirow[t]{2}{*}{ Latin America and the Caribbean } & -1.962 \\
\hline & $(1.052)$ \\
\hline \multirow[t]{2}{*}{ North America } & -1.560 \\
\hline & $(1.307)$ \\
\hline \multirow[t]{2}{*}{ Africa } & -0.236 \\
\hline & $(1.089)$ \\
\hline \multirow[t]{2}{*}{ Middle East and North Africa } & -1.398 \\
\hline & $(1.080)$ \\
\hline \multirow[t]{2}{*}{ Europe and Central Asia } & -0.962 \\
\hline & $(0.989)$ \\
\hline Western Europe & - \\
\hline
\end{tabular}

Observations

133

Standard errors in parentheses

$* * * \mathrm{p}<0.01, * * \mathrm{p}<0.05$

${ }^{25}$ There is a $10 \%$ data missing in this model. I ran the model without this variable and ran it with imputed values, based on multiple predictors, and the results did not change. 
More specifically, a state with a high score for Western-ness has over $80 \%$ probability of being an Entrepreneur or a Supporter and around 50\% probability of being an Entrepreneur (Graph I). An archetypical case of high support for the Rome Statute, Germany, both scored close to the maximum value in Western-ness (2.43/3), and the minimum value in PMID (0/77) and US assistance (0/21). It is not surprising therefore, to find Germany among the Rome Statute Entrepreneurs. Germany, led by Hans Peter Kaul was amongst the most vocal supporters for a Court with "teeth" (Kress, 2006: 36). On the other extreme, China appears as the archetypical case of low support for the Rome Statute, with low scores on Western-ness (0.04/3) and high involvement in militarized interstate dispute (57/77). In line with this expectation, China acted as a Detractor, arguing for a court with limited jurisdiction over restricted types of crime (Tao, 2015: 1097). Finally, the United States, which on the basis of its Western-ness score should have been an Entrepreneur, voted against the Statute. Indeed, while the United States supported the creation of an international criminal court, it rejected the notion of inherent jurisdiction and insisted on subordinating the Court to the United Nations Security Council (UNSC) in relation to the crime of aggression (Struett, 2008: 92, 94). Accordingly, the United States became a Detractor, not unlike China.

\section{Graph I: Probability Predictions Western-ness}

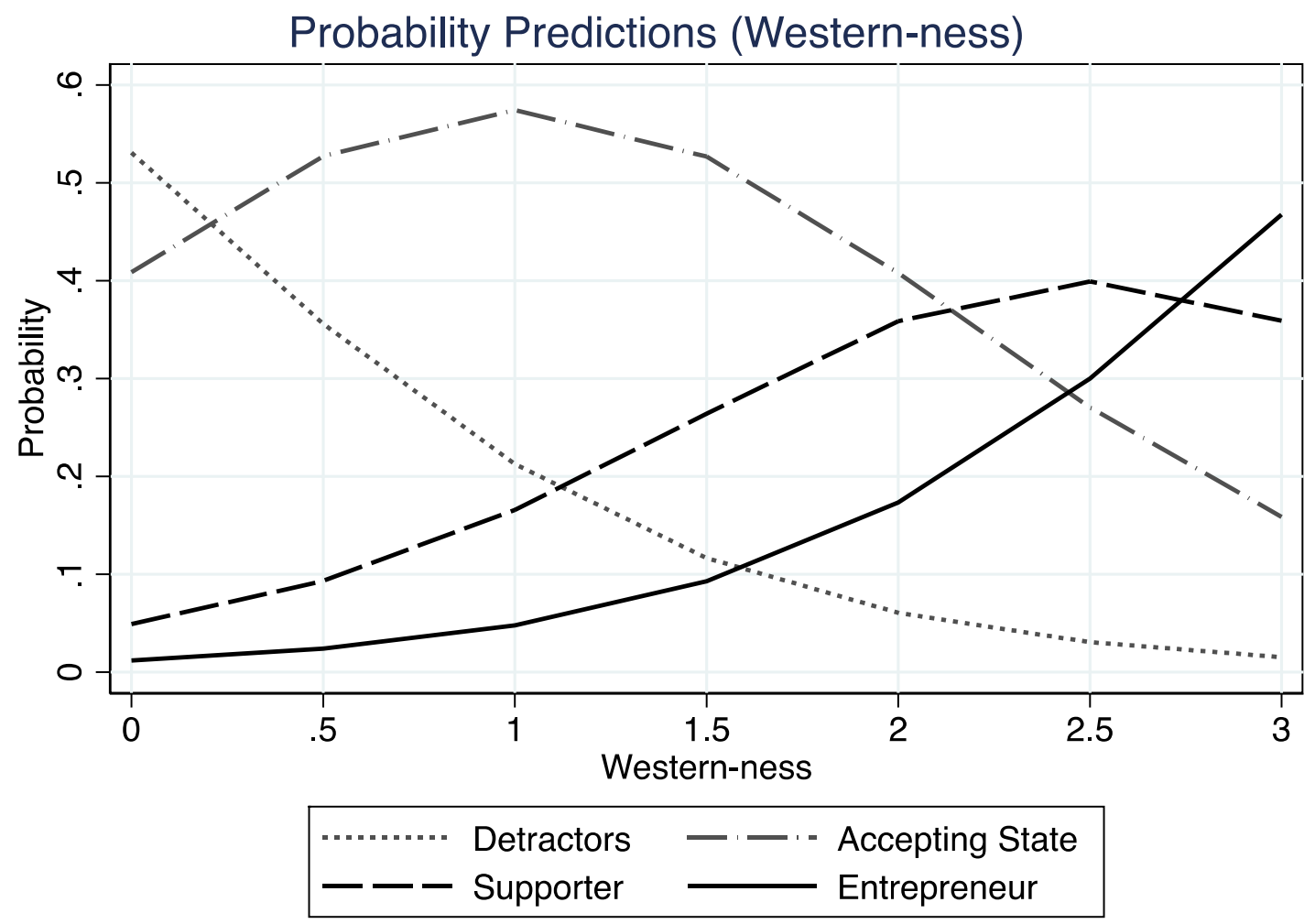

What explain the United States role as a detractor is its exceedingly high involvement in militarized interstate dispute. PMID, and to a lesser extent US Assistance both had a significant negative impact on states' support for the Rome Statute (Graph II and Graph III). For example, all other things being equal (at means), a country scoring high in Western-ness (2.7/3) is 
predicted to be an Entrepreneur (Graph I). However, the model also predicts that such a country would become a Detractor if it scored high on PMID (52/77) (Graph II). This is particularly relevant to understand a case like the US, in which material considerations imposed definitive limits over ideational variables. An instrumental logic based on the level of exposure that its high PMID created for it, led the US to a preference for an international criminal court subordinated to the Security Council and to vote against the Rome Statute.

Graph II: Probability Predictions Participation in Militarized Interstate Disputes

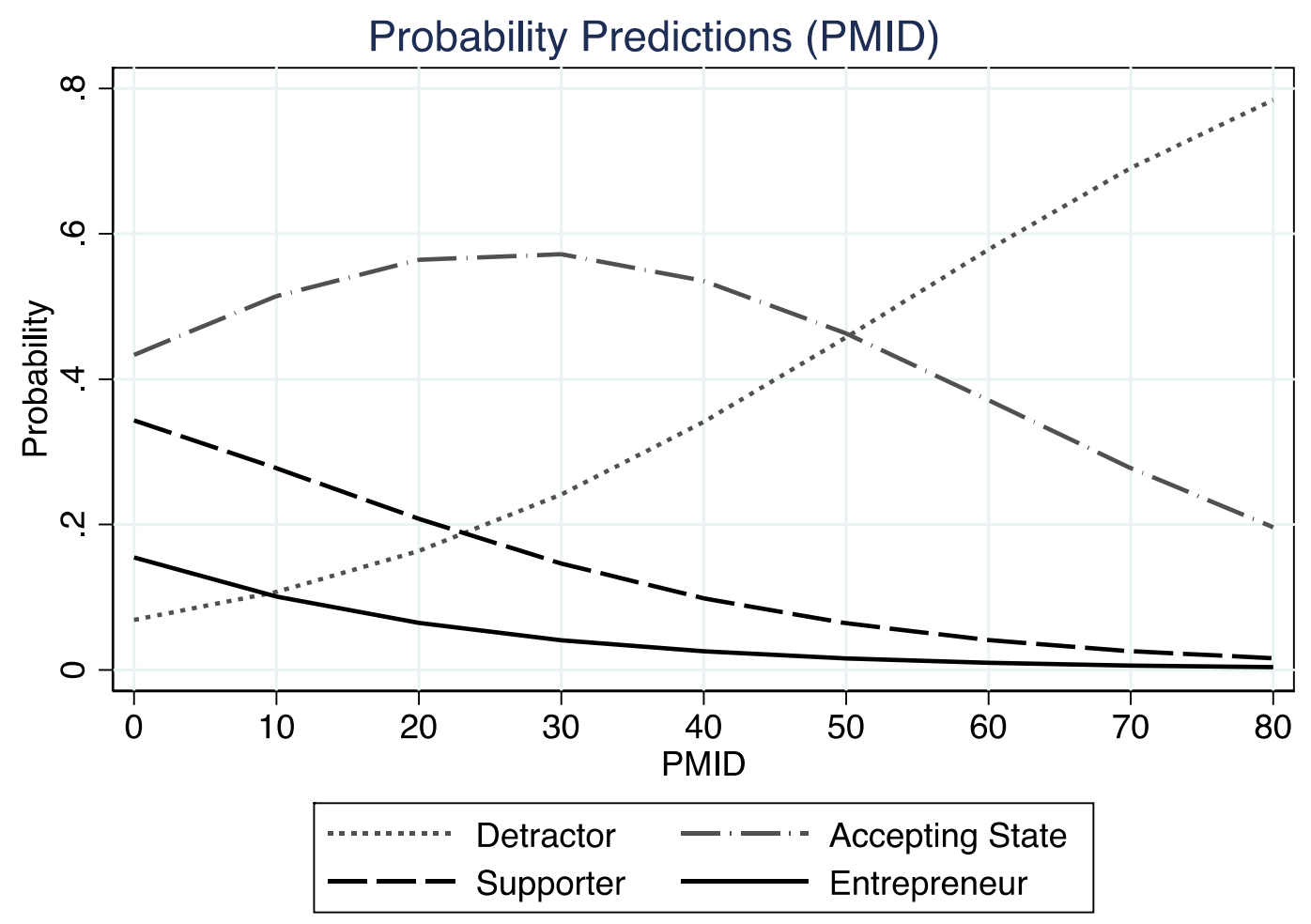




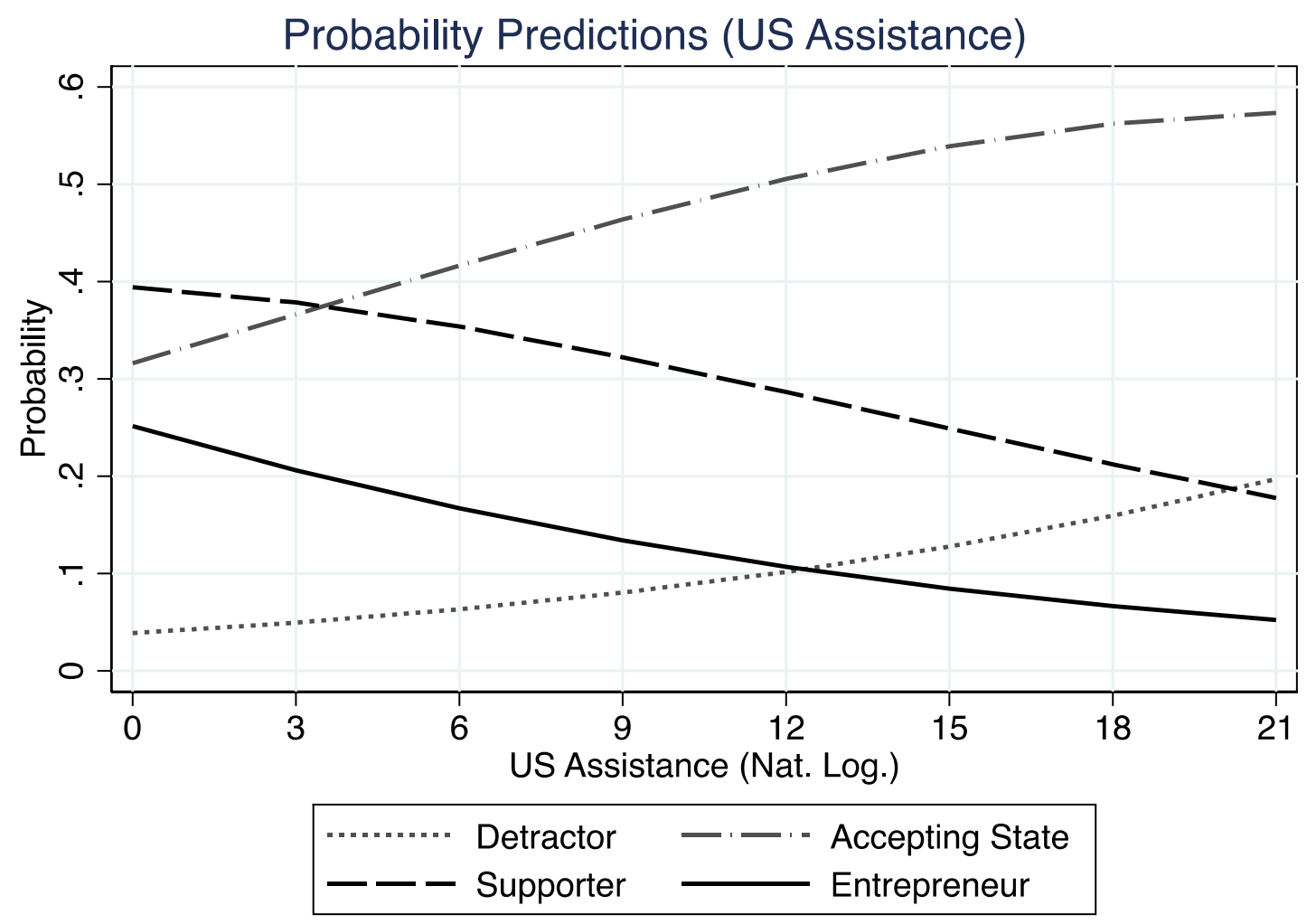

However, in order to outweigh the impact of high values in Western-ness the level of PMID has to be extremely high (Graph IV). The US level in this variable is almost eight times the average level of involvement (10/77). A country like France, which has over twice the average level (24/77), is still predicted to be an Entrepreneur (4) ${ }^{26}$. When we analyze the effect of US Assistance, it appears that it does not outweigh the positive effects of Western-ness like PMID does. For example, Hungary, which has high values in Western-ness (2.73/3), and US Assistance (16/21), is still predicted to be an Entrepreneur.

${ }^{26}$ France was in actuality, an ICC accepting state and not an ICC Entrepreneur 
Graph IV: Probability Predictions Participation in Militarized Interstate Disputes for Countries that score high on Western-ness

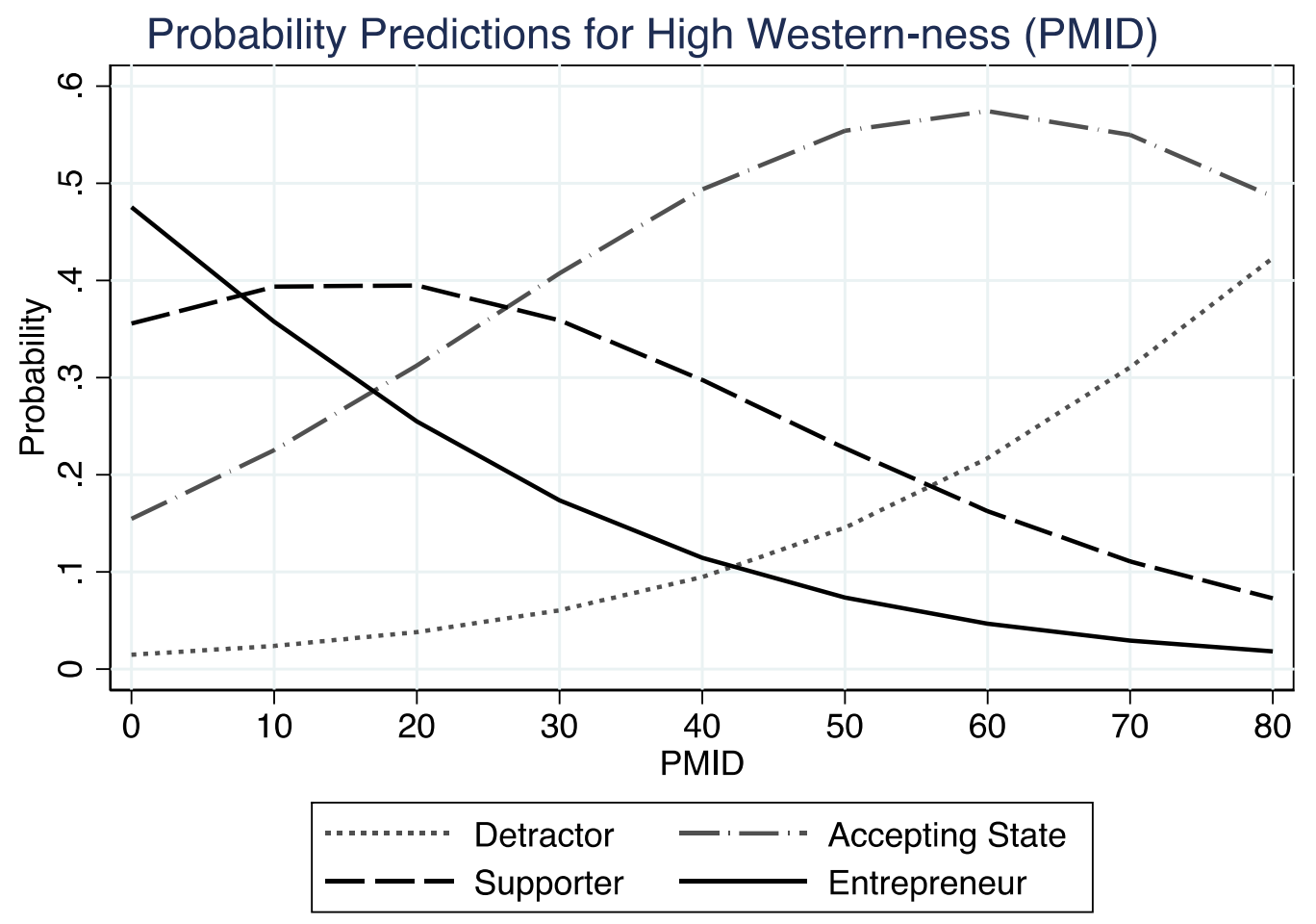

When we examine the marginal effects of the significant variables, we find that the average effect of the change on one unit of Western-ness on a country's level of support for the Rome Statute (all other things being equal at means) is of approximately 15\%. More specifically, an increase in one unit of Western-ness raises the chances of a country of becoming an Entrepreneur or Supporter by $33 \%$ - that is, it is 33\% more likely that the country will be a LMG state advocating for a strong independent court. Alternatively, an increase in one unit of Western-ness decreases the chances of becoming a detractor by $14 \%$. Similarly, the average effect of a comparable change in $\mathrm{PMID}^{27}$ decreases the probability of becoming a Support or an Entrepreneur by $30 \%$ and it increases the probability of becoming a detractor by $12 \%$. This kind of change, however, is highly unlikely. Indeed, while values of Western-ness are evenly distributed between the lowest (0) and highest (3) values PMID values are skewed towards zero. More specifically, there are only a handful of states that score above twenty in PMID.

27 To make the changes in Western-ness and PMID comparable we analyzed their marginal effects taking under consideration what percentage of possible total change they represented. One unit change on Western-ness entailed a 33\% change of the total range. We used this as a parameter to analyze the marginal effects of PMID. Specifically, we multiplied the $(-+1 / 2)$ coefficients by $33 \%$ of PMID total possible value (26). 


\section{Enabling Conditions for Persuasion}

In addition to explaining support for the Rome Statute, the findings illuminate a dimension of the negotiation that speaks directly to the ongoing legitimacy crisis of the ICC. Wiener's theory of contestation explains that in the absence of regular and institutionalized access to contestation (contestedness) unavoidable contestation will turn into conflict. In the context of negotiating the Rome Statute, limited resources precluded this possibility. This is not a new observation. On the contrary, the support that NGOs offered small delegations in Rome is part of the prevailing narrative on the adoption of the Rome Statute (Struett 2008; Deitelhoff 2009). The contribution of this paper is that it establishes the impact of wealth in the ability of states to formulate and signify their preferences by underscoring the impact of GDP on Westernness.

While GDP is not a relevant explanatory variable per se, it does have an interaction effect with Western-ness. Creating a threshold that divides poor and rich countries ${ }^{28}$ enables us to understand the impact of the significant variables on the behavior of each group of states. Specifically, we find that the effect of Western-ness is weaker on poor countries (Graph V). Indeed, whereas rich countries go from Accepting States to Entrepreneurs when the their score for Western-ness goes from low (0.5/3) to high (2.7/3), poor countries remain Accepting States until they reach medium-high values for Western-ness (2.3/3). Furthermore, at high values of Western-ness (2.7/3), they are most likely to become Rome Statute Supporters and not Entrepreneurs. In contrast, we cannot establish interaction effects between GDP and PMID or US assistance because they are not statistically significant for both poor and rich countries.

\footnotetext{
${ }^{28}$ Poor countries are those that scored 24 or less in the variable GDP -that is, natural logarithm of GDP for 1998. The median and average values of this variable are slightly above 23 .
} 
Graph V: Probability Predictions Western-ness for Rich and Poor Countries

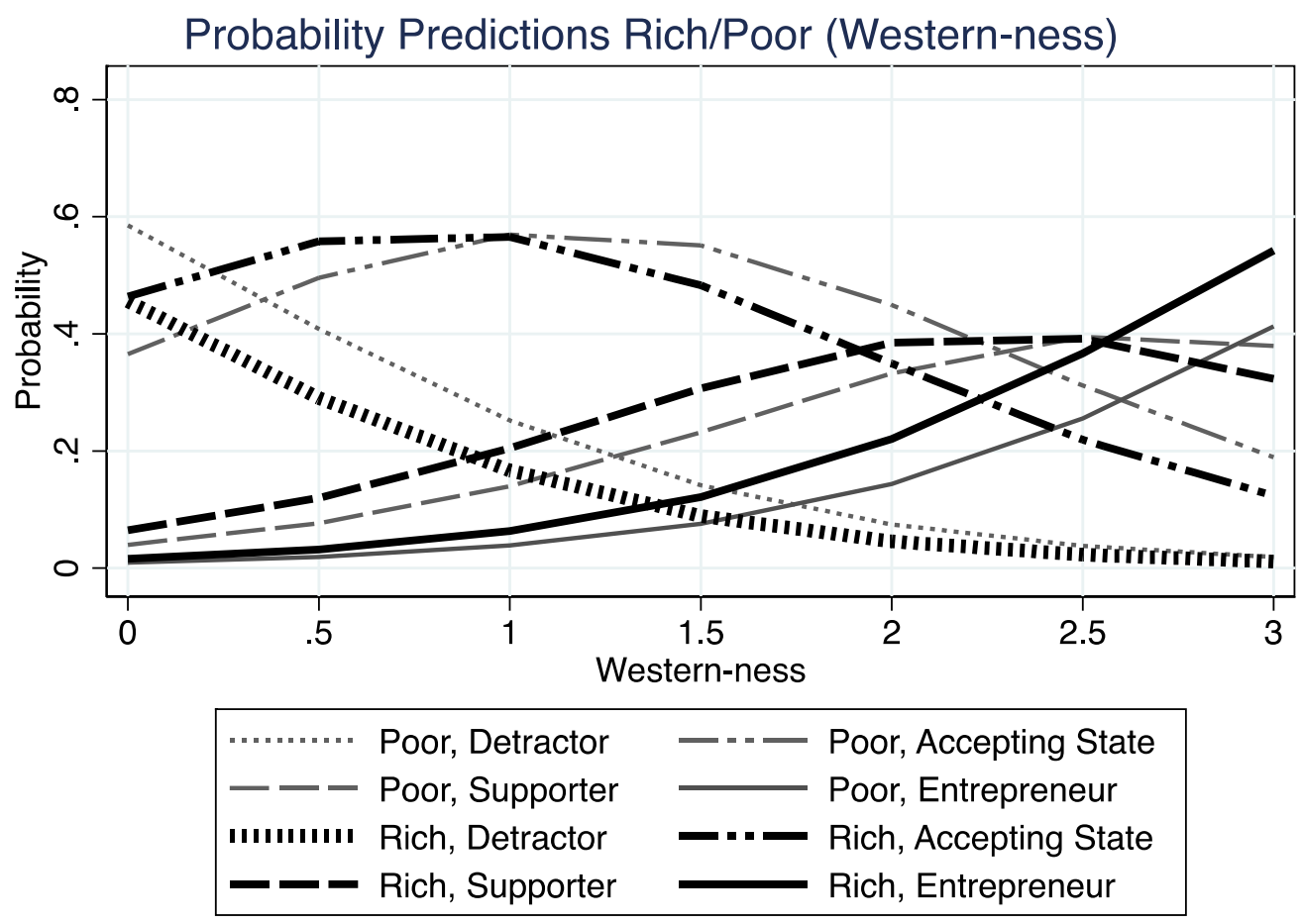

This speaks to the impact that lack of resources had on states' ability to formulate and signify their preferences. The mechanisms underlining this relation are the extent and quality of participation in the negotiation. Indeed, many states were unable to participate the negotiations that preceded the Rome Conference (Glasius 2002) because of their limited resources. ${ }^{29}$ Furthermore, said limitations meant that numerous states lacked the technical expertise that would have allowed them to fully engage in the design of the court (Benedetti and Washburn 1999, 17). In addition to this, due to the frantic pace of the negotiations in Rome only delegations with ten delegates or more were able to establish clear preferences (Bassiouni 1999, 450, footnote 27). Yet, limited resources meant that only about a third of delegations had that manpower (United Nations 1998). Some countries with small delegations - provided that they had extreme values of Western-ness, PMID or US assistance- could still develop clear preferences early on in the negotiation. That is the case of Ireland, which scored high in in Western-ness (2.85/3) and low in PMID (0/77). However, a majority of small delegations were unable to do so, making them susceptible to persuasion. This is the case for many African nations, some of which are amongst the strongest critics of the ICC today.

${ }^{29}$ There is a strong positive correlation between GDP and number of recorded participations in the negotiations that preceded the Rome Conference as there is between these and support for the Rome Statute. When added to the model, however, participation before Rome is not statistically significant. 
Many African states participated in the preparatory stage and in the negotiation to a much lesser extent than other states. ${ }^{30}$ Additionally, to the extent that they participated, the Court that they envisioned was different from the one that came into existence. Indeed, their vision entailed particular understandings of universality, participation, complementarity, court independence, and sovereign equality that the Rome Statute does not embody (Gissel 2018). Amongst the characteristics that made the African vision different, the understanding of complementarity stands out. Gissel explains that, while for the LMG and the CICC complementarity ensured the end of impunity, for many African states complementarity entailed that the ICC was a court "for positively failed states, not for states with imperfect of politicized justice systems" $(2018,741)$. It was a vision that prioritized sovereignty over the anti-impunity norm. ${ }^{31}$ The fact that so many African nations supported the adoption of a statute that did not embody these priorities is arguably the result of successful persuasion.

The United States and other detractors attempted to exert influence over undecided states on the basis of both rational and strategic arguments (Struett 2008, 92, 94, 100-102, 125), ${ }^{32}$ but the LMG and CICC prevailed. Not only did they control the key leadership positions of the Rome Conference (Bassiouni 1999), but also numerous states came to rely on LMG delegations and the NGOs to keep up with the work conducted on the different working groups (Struett $2008,110){ }^{33}$ This created an opportunity for the LMG and the CICC to advance their arguments for a strong and independent court. Indeed, it allowed them to frame the problem and the options for under-resourced delegations. ${ }^{34}$

It is thus unsurprising that the official records of the Rome Conference show limited discussion of the issues that would later prove controversial for these countries- notably how the Court would deal with sitting Heads of State and Government and the use of amnesties (United

\footnotetext{
${ }^{30}$ Gissel explains that African states did not in their majority submit written comments on the 1994 ILC Draft Statute that was circulated nor did they participate in the Prep Coms. In addition, there were only six African states in the first Ad Hoc committee. It was only in the last meeting in April 1998 that wider participation was possible $(2018,730)$. Their low participation before Rome validates the idea that many African states did not enter the negotiation with clear preferences.

${ }^{31}$ Consider the Common Statement South African Development Community (SADC) issued in 1997. In this document, after affirming their support for a strong and independent court with complementary jurisdiction, state representatives "[r]eiterate that the basic principle underlying the settling up and operation of the Court should be the acceptance that the Court should contribute to the furtherance of the integrity of states generally as well as equality of states within the principles of international law" (Common Statement in Maqungo 2000, 43)

${ }^{32}$ The United States also sought to utilize its resources to influence small states (TerraViva 1998, 2; Struett 2008, 185)

${ }^{33}$ Interviews with states' delegates and NGOs' representatives in June and July 2009 confirmed this assessment.

${ }^{34}$ A member of the German delegation also was of the opinion that in that in the case of NGOs' relationships with small delegations, "NGOs might have been able to shape their positions." In discussion with the author (July $24^{\text {th }}, 2009$ ).
} 
Nations 1998)- ${ }^{35}$ but which were not critical to the adoption of the Rome Statute. When examining the history of the negotiation of the articles most relevant to the question of amnesties $^{36}$, we find that open discussion and negotiation on this issue appears rather limited. Because of their controversial nature, discussion and negotiation of the Statute's compatibility with amnesties, pardons and other measures, could have undermined consensus and success of the negotiation, which might explain their exclusion.

Consider the negotiation of the complementarity principle, which involved articles 17 and 20 amongst others. The Chair of the PrepCom and acting head of the Canadian delegation (an Entrepreneur state), Mr John Holmes decided that in his informal consultations on the complementarity principle, he would not include the issue of amnesties or pardons to facilitate building consensus on said principle (Holmes 1999, 45). Similarly, the PrepCom bracketed the question of pardons in relation to the principle of ne bis in idem dues to lack of time (Holmes 1999, 59). In the Rome Conference, Mr Holmes, who was asked by the Bureau to continue his role during the negotiation, urged the delegates not to reopen the substance of the provisions regarding admissibility and ne bis in idem (Holmes 1999, 51), which negatively affected the possibility of discussing the use of amnesties. Mr Holmes opted instead to rely on informal bilateral consultations to address the proposal of a new article on pardons and related issues (Holmes 1999, 51-52). However, the resulting proposal was never subject to open-ended discussion and was dropped from the final package (Holmes 1999, 60).

Consider also the case of Article 53. During the negotiation, states addressed the issue of "interests of justice", in particular in relation to article 53 (2) of the Rome Statute. This article requires that the Prosecutor consider whether "taking into account the gravity of the crime and the interests of victims, there are nonetheless substantial reasons to believe an investigation would not serve the interests of justice". The Statute does not define interest of justice, but observers have argue that the drafters intended to give the Prosecutor discretion on the matter and that to interpret interests of justice in line with the idea of interests of peace, in such a way that allows for the use of amnesties as part of broader processes of peace and reconciliation, could be interpreted as compatible with the Statute (Scharf 1999; Robinson 2003; Bassiouni 2005). For instance, Schabas explains that had there been "an amendment to Article 53(1)(c) to the effect that "interests of justice shall not be confused with the interests of peace", it would surely not have met with consensus" (2010, 663). Yet, in the absence of a substantial discussion on the meaning of "interests of justice" that addressed amnesties and other key instruments in peace processes, the first Prosecutor was able to interpret "interest of justice" in a narrow manner, stating that" $[\mathrm{t}]$ he interests of justice" must of course not be confused with the interests of peace and security, which falls within the mandate of other institutions, such as the Un Security Council" (Moreno-Ocampo in Nouwen 2012, 335). In order to support his point, the

\footnotetext{
${ }^{35}$ The paper the United States circulated on state practice of amnesties and pardons constitutes an important exemption. However, in its introduction, the paper states "The U.S. delegation has raised the difficult matter of how to address amnesties and pardons in the context of a statute for an international criminal court. This matter, however, has not been a subject of discussion in the negotiations" (U.S. Delegation 1997, 1), which justified its efforts to bring the matter into discussion. ${ }^{36}$ According to Scharf, these are Articles 16, 17, 20 and 53 (1999, 524-5).
} 
Prosecutor observed that the term interests of justice, although frequently used in the Statute and in the Rules of Evidence and Procedures, is not defined and that that "reviews of the preparatory works on the treaty also offer no significant elucidation". In other words, the absence of a recorded discussion validates his interpretation, which in turn undermines any serious consideration of the use of amnesties as potentially integral part of a peace process.

In addition to framing, the LMG and the CICC relied on education to persuade states to support a strong and independent court. In this regard, the regional conferences played a critical role (Appendix D). In these conferences, the LMG and the CICC were able to address the concerns and mistrust of target countries from the Global South and reassure them that it was not the case that "the ICC was being set up mainly to reinforce the dominance of major powers" or "to put their heads of state on trial" (Deitelhoff 2009, 55). This was critical to secure their support for the Rome Statute. The LMG and the CICC also engaged in shaming (Deitelhoff $2009,57)$ and lobbying (Lee 2013, 223) to advance their cause.

In no way does this paper argue that the LMG and CICC manipulated smaller delegations. Yet the asymmetry of resources between the $\mathrm{LMG}^{37}$ and $\mathrm{CICC}$, on the one hand, and smaller delegations, on the other, as well as the strategies the former utilized ${ }^{38}$ problematize $^{2}$ the notion that persuasion took the form of a rational exchange.

While the CICC played a critical role in the development of certain features of the Court, such as crimes of sexual violence (Van Der Vyver 2003), they did not lead the way in in creating a strong and independent court. ${ }^{39}$ In contrast, they supported the efforts of LMG states. Consider the evidence that Struett offers to support the argument that civil society led the way on the issue of jurisdiction. He notices, for example, that as early as 1997 Amnesty International argued that "the prosecutor should be able to initiate investigations in any case where the court has jurisdiction, even in the absence of a referral by the Security Council or a state complaint, based on information from any source and to submit an indictment to the Court"(Amnesty International in Struett 2008, 103). However, this is not unlike the position that Germany expressed on this issue the year before, during the PrepCom meetings. Indeed, the official press release for this meeting reads "Germany also called for the prosecutor being empowered to undertake prosecutions on his own" (United Nations 1996). Struett also argues that both Pax Romana and AI advanced arguments in favor of inherent jurisdiction before LMG states like Ireland and Australia did (2008, 94). Yet, already during the 1996 PrepCom, Ireland had expressed that "while the prosecutor could not 'have carte blanche or pluck ideas from the air', it could not be left to States to decide when the prosecutor should act. Because "no country affected would actually admit that its own legal system had broken down... the court should be in a position to move in precisely when the national judicial system had broken down." (United Nations 1996).

\footnotetext{
${ }^{37}$ Here I refer to the LMG as a whole. Some individual LMG states had very limited resources. ${ }^{38}$ Compare norm entrepreneurs "vertical strategies" of norm diffusion with the more inclusive approach of communicative entrepreneurs (Gonzalez Ocantos 2018).

${ }^{39}$ In the words of a member of the German delegation, "there were areas, not central to the heart of governmental interests... like women's rights, victims rights, gender issues... there I think they (the NGOs) were quite successful... States were happy to make compromises on areas that were not that sensitive." In discussion with the author (July $24^{\text {th }}, 2009$ ).
} 
Other states have suggested inherent jurisdiction even sooner. For example, during the Sixth Commission's $21^{\text {st }}$ meeting in 1992, Norway expressed its support for the creation of a court that would have jurisdiction over core crimes under international law and whose jurisdiction would be automatic and not subject to opt-out mechanism (United Nations 1992). Similarly, both Germany (United Nation 1995a) and Argentina (United Nations 1995b) stated their support for inherent jurisdiction in 1995.

Furthermore, while civil society organizations skillfully gained access and influence throughout the negotiation, only states could address some of the concerns of their undecided counterparts and thus had the ability to persuade them. Consider the case of France. While the model predicts France would be an Entrepreneur, it was an Accepting State instead- that is, France voted for the Rome Statute, but never officially become part of the LMG. The reason for the model's failure is that, like the United States, France is an outlier in terms of PMID. Indeed, France has a very high level of PMID (24/77), which led to concerns over a politicized prosecutor. Recent history did not help. The French military had been targeted by the ICTR and the ICTY, which had made them (and other actors in the French government) particularly distrustful of an independent international criminal jurisdiction such as the ICC. ${ }^{40}$ Accordingly, France adopted a tough negotiating position and kept it until the last day of the Conference.

Why did France revert its position? The answer is persuasion. It was not until they secured Article $124^{41}$ that the French delegation came to support the Rome Statute (Tabak 2009, 1073-4). Without this concession, France would have likely abstained in Rome. ${ }^{42}$ Indeed, while the delegation did not have the mandate to undermine the emerging court, it did have very clear instructions regarding the preconditions for French support and these were, in essence, nonnegotiable. ${ }^{43}$ In the case of France, persuasion was all about understanding political concerns and working with a counterpart within those limitations in a principled and pragmatic manner. That is what the LMG did.

In contrast to the French case, persuading the over two-dozen undecided African nations ${ }^{44}$ present at the Rome Conference did not involve making concessions. Instead, African LMG states levered previous commitments, such as the aforementioned Common Statement of the South African Development Community (SADC), and relied of the leadership of their delegates. In this regard, South Africa and Lesotho, both Entrepreneurs of the Rome Statute, stand out. On the last day of the Rome Conference, these countries convened meetings for the SADC states and the African Group respectively. As Maqungo explains, the SADC states, led by South Africa, decided to vote for the adoption of the less-than-ideal Statute. In turn, Lesotho persuaded most states in the African group to support the package deal put forth by the Bureau,

\footnotetext{
${ }^{40}$ Interview with French delegate (July 14th, 2009).

${ }^{41}$ Article 124 enables a state to "declare that, for a period of seven years after the entry into force of this Statute for the State concerned, it does not accept the jurisdiction of the Court with respect to the category of crimes referred to in article 8" (Rome Statute),

${ }^{42}$ Interview with French delegate (July 14th, 2009). See also Tabak (2009, 1073).

${ }^{43}$ Interview with French delegate (July 14th, 2009).

${ }^{44}$ This refers to the African states who had not become members of the LMG nor were overt critics, such as Sudan.
} 
prevailing over those voices in the group who believed the proposed statute was not acceptable, mainly due to the failure to include a definition of the crime of aggression (2000, 45). This ensured the success of the Conference, whose outcome was still largely uncertain in the final days. However, the manner in which this support came to be helps us understand why many African states did not develop, in Park and Vetterlein's words, ownership over the Rome Statute. Indeed, the participation of most African countries was limited throughout the process and issues of significance for African states were largely left out of discussion (amnesties) or left unresolved (aggression). Wiener's theory anticipates that the absence of engagement (proactive contestation) with norms negatively affects their legitimacy of norms. From this perspective the perceived turn in many African countries relation with the Court and its current legitimacy crisis is unsurprising.

The emphasis the argument places on the role of states is not a denial of the critical impact of the CICC. Indeed, the Coalition was able to garner support for the Statute amongst countries that were generally distrustful of the project because they feared would become an instrument of Western domination. Yet LMG states were in many instances better positioned to persuade their counterparts. Not only had they the power to strike compromises and concessions, but also, as states and not just norm entrepreneurs, they were more readily willing to engage in these practices. What could seem like capitulation for an NGO, a politician understood as a necessity in a negotiating context characterized by diverse interests and ideas. Consider again the inclusion of Article 124. While civil society actors denounced it as antithetical to the Statute and its purpose (CICC 1998), only two countries have invoked it to opt-out of the Court's (France and Colombia), with France withdrawing its invocation in 2008 and Colombia's seven-year ending in 2009. This political compromise thus guaranteed France's invaluable support and did not inflict irreparable damage on the Court. From the perspective of the CICC such compromises undermine the "anti-impunity" norm and are thus unacceptable. This intransigent attitude later pervaded their approach to the implementation of the Statute to the detriment of access to contestation for stakeholders.

\section{State Support After Rome}

The success of the conference emboldened supporters of the Rome Statute, who launched a successful ratification campaign. This campaign culminated with the entry into force of the Rome Statute on July $1^{\text {st }}$, 2002. Critical in this outcome was the CICC, which expanded its advocacy efforts at the service of the Court (Haddad 2013). Because of their prestige, which is a direct result of their success in promoting the adoption and later ratification of the Rome Statute, ${ }^{45}$ civil society advocates' uncompromising stance arguably has continued to shape the conversation. Their goal is to preserve the integrity of the anti-impunity norm, ${ }^{46}$ which they

\footnotetext{
45 In 2002, only four years after its adoption and notwithstanding strong opposition from the United States (Betti 2016), the Rome Statute came into force. Currently there are 123 states parties to the Statute.

${ }^{46}$ The vision of the CICCC is "a more peaceful world through universal access to justice for victims of war crimes, crimes against humanity and genocide" (CICC website).
} 
helped endow with formal validity through the adoption and ratification of the Rome Statute. Accordingly, they have utilized their status to limit the scope of what is acceptable behavior in light of the Statute (García Iommi 2019). For example, they have actively pursued the incorporation of the Rome Statute as such in domestic legal systems, which they interpret is the only way member states can meet their obligations with the Court (Cattin 2012, 373). They have also undermined the use of amnesties, presenting them as antithetical to the Rome Statute (Naqvi 2018). To achieve their goals they have resorted to the same strategies they relied on during the negotiation, notably education. ${ }^{47}$ However, because contestation is inevitable and necessary for the legitimacy of norms and the institutions that embody them, this approach is fostering conflict instead of compromise. The lesson has not been learned. The adoption of the Rome Statute and its entry into force endowed the norms embodied in the Statute with formal validity, but they lack the legitimacy that stakeholders' proactive contestation generates. This problem underlines the current legitimacy crisis of the Court.

This conflict is most notable in relation to African states. The reason is that the ICC, through self-referral, United Nations Security Council referrals, and propio motu investigations, has focused mostly in this part of the world. In particular, the Kenyatta case and the arrest warrant against al-Bashir galvanized collective and individual contestation efforts (Bower 2019). While some have argued contestation in this context indicates a reversal in previously held positions among African states (Mills and Bloomfield 2018), this paper explains that many African states never took ownership of the Statute. While some African states were part of the LMG and firmly committed to the creation of a strong and independent court that could put a halt on impunity, these states constituted a minority.

As already noted, to the (limited) extent that African states participated in the discussions leading to the adoption of the Rome Statute, ${ }^{48}$ they envisioned a Court that was substantially different from the one that emerged, in part as a result of their limited access to proactive contestation. Indeed, it is not far fetched to argue that, had African states possessed the autonomy that derives from possessing the resources necessary to realize preferences and advance them, a very different dynamic would have been fostered between the Court and its African stakeholders during the negotiations over the Rome Statute. Specifically, it would have increased the sense of ownership amongst African stakeholders and limited reactive contestation moving forward, positively affecting the legitimacy of the Court.

On the basis of this premise, this section examines the overall pattern of support for the ICC after the Rome Conference. To measure support after Rome, it relies on a new variable

47 The Coalition has produced informative materials, conducted workshops and training sessions worldwide to explain local actors how to implement the Statute. Some of these materials are available online through the CICC website or the websites of NGO members. See, for example, the implementation guidelines made available by Amnesty international and the guidelines for Parliamentarians in the Parliamentarians fro Global Action website.

${ }^{48}$ García Iommi emphasizes the degree to which this participation was limited, explaining that while the average number of recorded statements per state in the drafting process leading to Rome was thirteen (and 23 for European states) the number is fewer than three for African states $(2019,7)$. 
(Post Rome Support) that measures support combining five indicators: membership, implementation of cooperation legislation, implementation of complementarity legislation, adoption of the Agreement on Privileges and Immunities (APIC) and resistance to pressure by the United States to sign Bilateral Immunity Agreements (BIAs). ${ }^{49}$ The evidence demonstrates that patterns of support that emerged before the adoption of the Rome Statute continue to influence states' relation with the Court today. Entrepreneurs and Supporters of the Rome Statute continued to demonstrate greater support for the Statute after Rome. Specifically, Entrepreneurs have on average displayed $80 \%$ as much support as Accepting states. Supporters, in turn, have been $50 \%$ more supportive. Indeed, while $82 \%$ of Entrepreneurs have showed high support for the Rome Statute post Rome, only $27 \%$ of Accepting states have. ${ }^{50}$

Graph VI: Average Post-Rome Support for the ICC Score

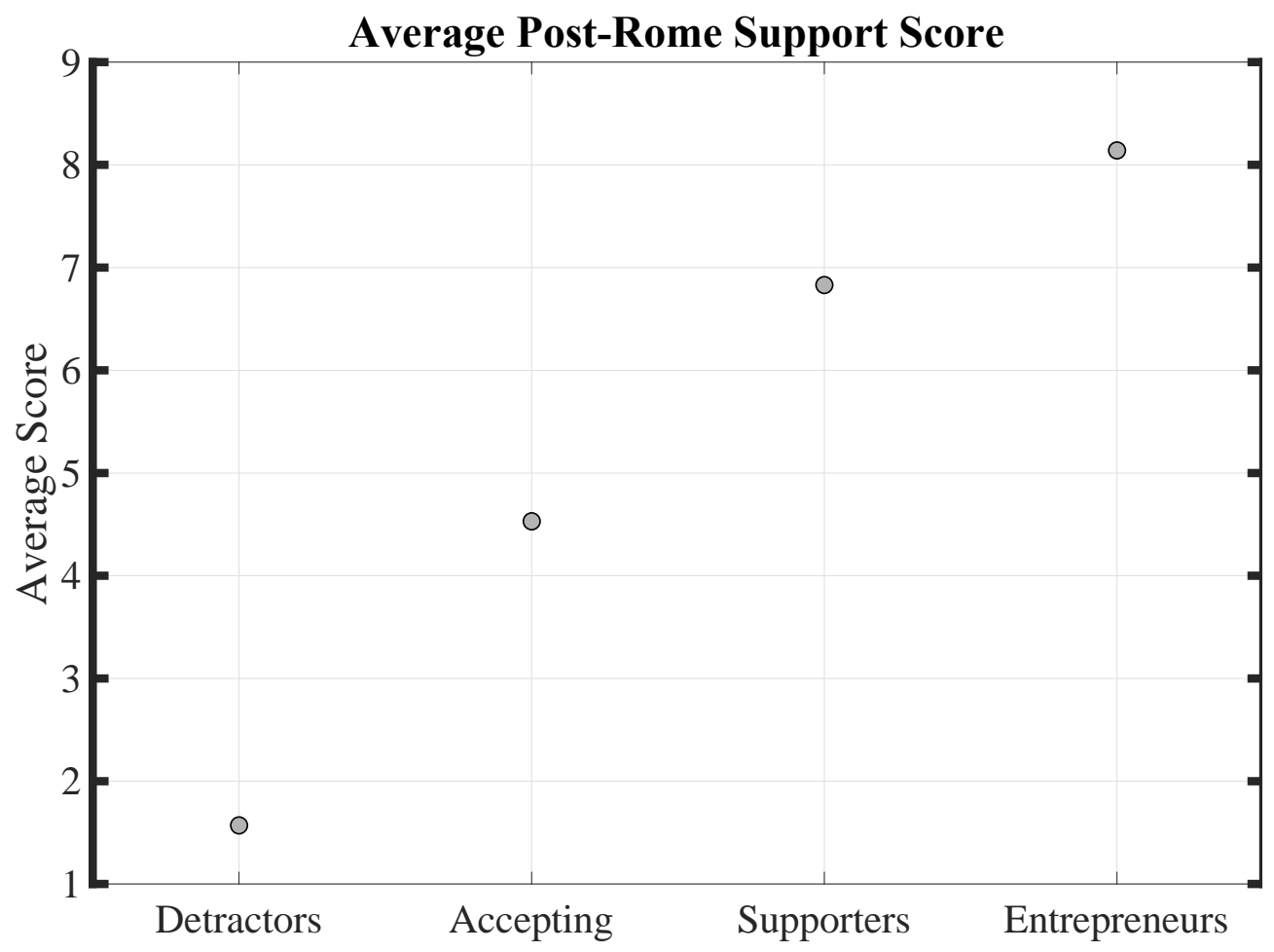

${ }^{49}$ Membership varies from 0 to 2 (the score for signature is 1 and for ratification or accession is 2), implementation of cooperation and complementarity legislation varies from 0 to 2 (the score for a draft is 1 and score for enacted legislation is 2), adoption of the APIC varies from 0 to 2 (the score for signature is 1 and for ratification or accession is 2) and resistance to BIAs varies from 0 to 1 (the score for not signing is 1 and for signing is 0 ). The data for these variable is available in the CICC website.

${ }^{50}$ I define high support as ratification (2) plus some combination of the other variables for a total score of 6 or higher. 
Graph VII: Percentage of States with High Post-Rome Support for the ICC

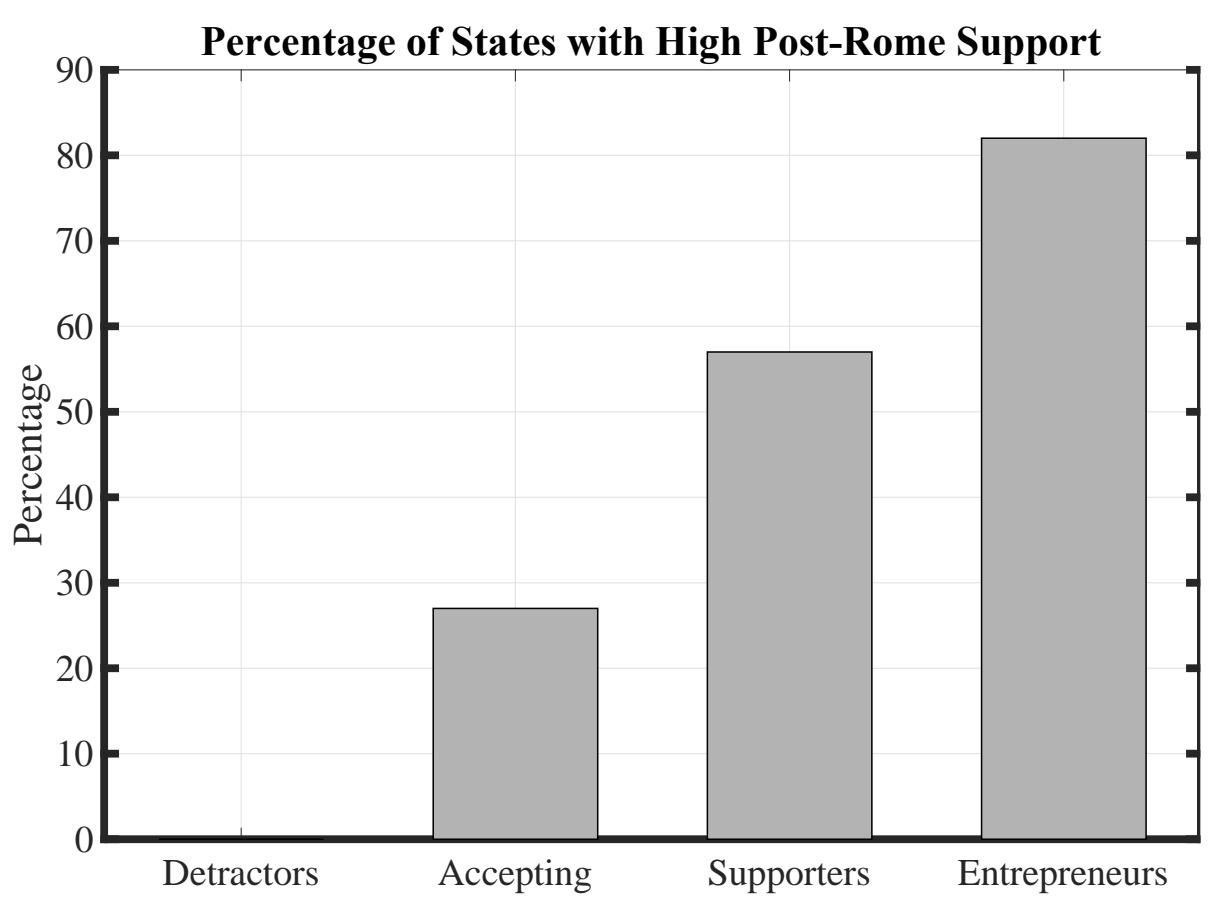

This broad pattern of support helps us understand the enduring impact of the process that led to the adoption of the Rome Statute. In particular, it allows us to differentiate between strong supporters, who on the basis of their identity advocated for a court of the characteristics of the ICC, and those whose who were persuaded to support the adoption of the Statute. Furthermore, the preferences that some of these states failed to articulate or have included in the discussion during the preparatory and negotiating stages of the Rome Statute manifested later on as low support for the Court -or even conflict. Indeed, when we consider the cases of Uganda, Kenya, and the Democratic Republic of Congo (DRC) ${ }^{51}$ all accepting states that ratified the Statute, it becomes clear that a different vision for the Court, which was mostly absent from discussion in the process leading to the adoption of the Rome Statute, prevailed in these countries.

Let us consider in detail the case of Uganda. This country was amongst the first states to sign and ratify the Rome Statute. Having signed the treaty in March 1999, it ratified it June 2002, a few months before the treaty entered into force. In contrast with the expediency of signature and ratification, implementation did not take place until 2010. Uganda passed the ICC act in advance of its role as host of the Review Conference of the Rome Statute in 2010, after two previous drafts in 2004 and in 2006 did not make it into law - or even made much progress in the legislative process. Some scholars have persuasively argued that the pressure of hosting the conference helps explain the timing of the implementation process (Nouwen 2013, 198). Previous failure can be tied to disagreements over the proper implementation of the Statute in relation to other justice mechanisms. Indeed, the main concern raised by legislators during the debate focused on the Statute's relation with traditional forms of justice and the use of amnesties

\footnotetext{
${ }^{51}$ The fact that the ICC has opened investigations and cases in all three countries further establishes the usefulness of these cases to evaluate Accepting states relation with the Court.
} 
(De Vos, 2015: 392). Relevant to this argument is the fact that in 2009, the Northern Ugandan Transitional Justice Working Group (TJWG) attempted to promote the simultaneous discussion of an ICC implementation bill and a bill that embodied traditional forms of justice; Parliament decided, however, under pressure from government donors, to pass the ICC implementation bill fast at the expense of a more inclusive process (De Vos 2015, 392).

In spite of the successful external pressure of pro ICC advocates, unresolved tensions between the Statute and Uganda's long tradition of using amnesties, which has strong popular support, eventually led to conflict. Indeed, when rumors circulated that upon renewal the Amnesty Act would not include the amnesty component, which pro ICC advocates condemned, civil society representatives asked Parliament to having it reinstated. This prompted Parliament to request the Defence and Internal Affairs Committee that they make a recommendation on the matter. In its report, the Committee recommended to reinstate the amnesty provision in the law, stating that " $\mathrm{t}]$ here is a greater need for African states to be more assertive in ensuring that their values are reflected in the development of international law" (Report in De Vos 2015, 400). ${ }^{52}$

The question remains: why would Uganda vote for the adoption of and ratify the Rome Statute if it entailed a vision of justice it did not fully ascribed to? Arguably the government of Uganda envisioned a Court that would assist it in its efforts to address their Lord Resistance Army (LRA) problem. ${ }^{53}$ When it started perceiving it as an obstacle, it adopted a more challenging attitude vis-à-vis the Court (Mills and Bloomfield 2018, 120). This dynamic speaks to the potentially shallow conversion of Accepting states and the limits of formal validity alone to shape states' behavior. It is tempting to altogether dismiss the role of norms in assessing Uganda's relation with the Court, but that would be a mistake. The fact that Uganda is not as deeply committed to the anti-impunity norm as Entrepreneurs and Supporters are does not entail that norms did not play a role in determining Uganda's relation with the Court. As Gissel demonstrates, within the parameters of its limited participation, Uganda's vision for the Court was one that reasserted state sovereignty as illustrated by its views on complementarity (2018, 742). From this perspective, current clashes are shaped by different normative priorities (García Iommi 2019), which preceded the adoption of the Rome Statute but were not sufficiently part of the discussion and negotiation before the implementation stage.

It is worth mentioning that not all Accepting states, including African Accepting states, have developed a conflictive relation with the ICC. ${ }^{54}$ In 2016 Botswana, Nigeria, Senegal,

\footnotetext{
${ }^{52}$ While the discussion focused on Uganda, other Accepting states also struggled to fully cooperate with the Court on account of amnesties. Armenia, another Accepting state, could not ratify the Statute because its Constitutional Court rendered a negative opinion on the compatibility of the Statute with its domestic legal system on the grounds that national authorities would be deprived of the right to grant pardon (CICC 2012)

53 This argument fits with Hillebrecht and Strauss argument that that cooperation with the Court is contingent upon domestic political gain, such as the possibility of using the ICC to constrain or remove domestic opposition actors $(2017,163)$.

${ }^{54}$ In terms of the relation of Accepting States with the ICC today, Colombia constitutes an interesting case. The ICC did not open an investigation in Colombia but played an important role in the peace process. Colombia signed the Rome Statute in 1998 and ratified it in 2002. As a
} 
Tunisia, Ivory Coast and Algeria, all Accepting states, pushed back against the African Union call for mass withdrawal, preventing its discussion in the $27^{\text {th }}$ African Union Summit (Mills and Bloomfield 2017, 122). Furthermore, two African Accepting states, Tunisia and the Ivory Coast, have joined the ICC since the al-Bashir debacle prompted the African Union to overtly challenge the Court. It is also not the case that strong support for the Rome Statute ensures strong support today. Indeed, South Africa was an Entrepreneur state, yet it failed to arrest al-Bashir in 2015. Moreover, South Africa announced its intention to withdraw in 2016. Nevertheless, the positions that African states adopted towards the Statute are, overall, a good predictor of how supportive these state are of the ICC today. Similarly, the relative absence of African voices in the process of drafting and negotiating the Rome Statute, which limited the access to proactive contestation of these stakeholders, is an important part of the current legitimacy crisis in the region.

\section{Conclusions}

The al-Bashir investigation realized the fears that some states had prior to being persuaded to support the Rome Statute. Indeed, al-Bashir was the sitting President of a non-party African state in a situation of on-going conflict. Furthermore, the ICC initiated its investigation at the bequest of the powerful UNSC. This combination of factors fostered African solidarity in resistance to the Court, even among strong ICC supporters like South Africa, and led to intense contestation (Boehme 2017). In light of the evidence considered here, it is possible to argue that the absence of meaningful discussion of issues germane to some ICC stakeholders (proactive contestation) during the negotiation contributed to the adoption of the Rome Statute, but also plausibly created additional difficulties for the Court in the long run. Furthermore, it undermined the possibility of some stakeholders developing a sense of ownership over the Rome Statute because they did not fully participate in its design. In this interpretation of the events, persuasion did not fundamentally altered stakeholders' support for the Court, but created a large number of mildly supportive member states. This is not the sole or even plausibly the primary reason of the current ICC legitimacy crisis. Moreover, in the process of diffusion, interpretation and implementation of the Statute, further involvement of diverse stakeholders could have generated a sense of ownership that may have facilitated the necessary compromises. The fact that this did not happen greatly contributed to the crisis. However, in light of Wiener's theory, the evidence considered in this paper successfully challenge the notion that the problems started with the arrest al-Bashir, which has dominated to a large extent the narrative of the crisis.

result of the extreme violence that characterizes its fifty-year old conflict it has also been under preliminary examination by the Office of the Prosecutor since 2004. Yet the role of the Court in this country has been consultative rather than direct, in line with the idea of positive complementarity (Hillebrecht, Huneeus and Borda 2018). Differences between the ICC and Colombia have arisen, with Colombia asserting its primary jurisdiction over crimes committed in its territory, upholding a strategy informed by transitional justice in contrast to the ICC's retributive approach (Easterday 2015, 449). Colombia's ability to withstand pressure is not in small measure the result of its resources, specifically the legal expertise of local actors. 
The paper demonstrated the significant role that identity as well as participation in militarized interstate disputes and US assistance played in the adoption of the Rome Statute. Germany, China and the United States illustrate states' behaviour at extreme values of the relevant variables. The German delegation became an Entrepreneur, while China acted as a Detractor. ${ }^{55}$ In turn, the United States, which on the basis on its Western-ness score should have been an Entrepreneur, ${ }^{56}$ voted against the Statute because of its exceedingly high involvement in militarized interstate disputes. France was in a similar situation (albeit not scoring as exceedingly high in PMID as the US) but was susceptible to persuasion on the basis of a political compromise. Many African states were persuaded to vote for the adoption of the Rome Statute, but without the benefit of concessions that reflected their interests and normative priorities. This ensured the success of the negotiation but did not provide the foundations for a legitimate court.

The paper also identified the conditions that made it possible for advocates of a strong and independent court to persuade a large number of states to support the Rome Statute, emphasizing the role of limited resources in states ability to formulate and signify their preferences. In addition to this, it highlighted the importance of the LMG states in the process. Finally, the paper connected the impact of limited resources to states' inability to fully participate in the preparatory work and negotiation of the Rome Statute and explained its enduring negative impact on the legitimacy of the ICC both in terms of the impossibility of creating necessary compromises on key issues early on and in relation to fostering stakeholders' ownership over the Statute and thus its legitimacy and their support for it.

An additional source of concern in terms of the legitimacy of the ICC relates to the high impact of Western-ness on states' support for the Rome Statute. The significance of Westernness in contrast with the other dimensions of state identity (Legalism and Proximity to Core) could be interpreted as evidence that the Court is not impartial. Indeed, it seems to reaffirm the suspicion that there are inherent hegemonic biases in the Rome Statute (Cowell 2017; Tallgreen 2015). Yet, even if that is the case, fostering the legitimacy of the Court is still possible. As Wiener explains, norms are inherently contested and only acquire meaning when they are implemented $(2008,2014)$. In the implementation stage of norms, contestation over their cultural validation is expected and could lead to either conflict or compromise (Wiener 2014). Therefore we should expect contestation over the proper implementation of the Statute. If stakeholders enjoy inclusive, regular and institutionalized access to contestation (contestedness), compromise and even consensus might ensue. In turn, this would foster the legitimacy of the ICC. In other words, the actual meaning of the Rome Statute and the norms it embodies is not fully determined. Moreover, ample opportunities exist to foster its legitimacy through appropriate stakeholder engagement.

Bearing in mind that the negotiation of the ICC was a relatively inclusive process, some of the limitations in terms of access to contestation that we identified in this case create a far more dire outlook for most international institutions. This makes it imperative to open spaces for

\footnotetext{
${ }^{55}$ We can also characterize detractors as antipreneurs (Bloomfield 2015). Indeed, while the LMG and the CICC advanced the creation a strong and independent Court, China and the United States, among other states, advocated for a status-quo institution.

${ }^{56}$ All other variables at means.
} 
regular and institutionalized access to contestation for all stakeholders. This is not a novel claim in the norms literature but, unlike most contributions, this paper emphasizes the risks associated with the intransigent approach of civil society actors and the significant role that political actors could play in the process. This is not to say that civil society does not have or should not have a role in the conversation. Far from it. A more inclusive process is arguably more likely to succeed in advancing effective and fairer global governance. The suggestion is that we recognize that, in a diverse world, norms and norm dynamics are political. Accordingly, we should not recoil from contestation amongst stakeholders but encourage it.

\section{Bibliography}

Acharya, Amitav (2004) "How ideas spread: whose norms matter? Norm localization and institutional change in Asian regionalism", International organization, 58:2, 239-275.

Abbott, Kenneth and Duncan Snidal (2000) "Hard and soft law in international governance", International organization 54:3, 421-456.

Arcudi, Antonio (2019) "The Absence of Norm Modification and the Intensification of Norm Contestation: Africa and the Responsibility to Prosecute", Global Responsibility to Protect 11:2, 172-197.

Ashizawa, Kuniko (2008) "When identity matters: State identity, regional institution-building, and Japanese foreign policy", International Studies Review 10:3, 571-598.

Assembly of States Parties to the Rome Statute (2019) Chronological List of States Party to the Rome Statute, https://asp.icc-

cpi.int/en_menus/asp/states\%20parties/Pages/states\%20parties\%20_\%20chronological\%20list.as px

Barnett, Michael (2002) "The Israeli identity and the peace process: re/creating the un/thinkable" in Shibley Telhami and Michael N. Barnett (eds) Identity and Foreign Policy in the Middle East (Ithaca, N.J.: Cornell University Press), 58-87.

Bass, Gary Jonathan (2000) Stay the Hand of Vengeance: The Politics of War (Princeton, NJ: Princeton University Press).

Bassiouni, M. Cherif (1999) "Negotiating the Treaty of Rome on the establishment of an International Criminal Court", Cornell International Law Journal 32:3, 443-469.

Bassiouni, M. Cherif (2005) The Legislative History of the International Criminal Court: Introduction, Analysis and Integrated Text. (Ardsley, N.Y.: Transnational Publishers). 
Benedetti, Fanny and John L. Washburn (1999) "Drafting the International Criminal court Treaty: Two Years to Rome and an Afterword on the Rome Diplomatic Conference" Global Conference 5, 1-37.

Benedetti, Fanny, Karine Bonneau, and John Washburn (2013) Negotiating the International Criminal Court: New York to Rome, 1994-1998 (Leiden, The Netherlands: Martinus Nijhoff Publishers).

Betti, Andrea (2016) “"'Slay This Monster”: the United States and Opposition to the Rome Statute on the International Criminal Court”, Human Rights Review 17:4, 417-438

Bloomfield, Alan (2016) "Norm Antipreneurs and Theorising Resistance to Normative Change", Review of International Studies 42:2, 310-33.

Boehme, Franziska (2017) "We Chose Africa': South Africa and the Regional Politics of Cooperation with the International Criminal Court", International Journal of Transitional Justice $11: 1,50-70$.

Bower, Adam (2019) "Contesting the International Criminal Court: Bashir, Kenyatta, and the Status of the Nonimpunity Norm in World Politics”, Journal of Global Security Studies 4:1, 88104.

Broomhall, Bruce (2003) International justice and the International Criminal Court: between sovereignty and the rule of law (Oxford: Oxford University Press).

Cattin, David (2012) "Approximation or Harmonization as a Result of Implementation of the Rome Statute" in L. van den Herik and Carsten Stahn (eds.), The Diversification of International Criminal Law (Leiden, The Netherlands: Martinus Nijhoff Publishers), 361-388.

Chenivesse Pascal and Christopher Piranio (2011) "What price justice? On the evolving notion of 'right to fair trial' from Nuremberg to The Hague" Cambridge Review of International Affairs $24: 3,403-423$.

CICC (1998) "Opting In on War Crimes Would Be "Retrograde Step for International Law" Warns Angry Red Cross", On the Record July 14 ${ }^{\text {th }}$, http://www.legal-tools.org/doc/8597e1/pdf/

CICC (2012) "Global Advocacy Campaign for the International Criminal Court. Chart on the Statute of Ratification and Implementation of the Rome Statute and the Agreement on Privileges and Immunities (APIC)", http://www.iccnow.org/documents/Global_Ratificationimplementation_chart_May2012.pdf.

Cowell, Frederick (2017) "Inherent imperialism: understanding the legal roots of anti-imperialist criticism of the International Criminal Court" Journal of International Criminal Justice 15:4, 667-687. 
Dean Moore, Kathleen (1989) Pardons: Justice, Mercy, and the Public Interest (New York: Oxford University Press).

Deitelhoff, Nicole (2009) "The Discursive Process of Legalization: Charting Islands of Persuasion in the ICC Case" International Organization 63:1, 33-65.

Deitelhoff, Nicole and Linda Wallbott (2012) "Beyond soft balancing: Small states and coalitionbuilding in the ICC and climate negotiations", Cambridge Review of International Affairs 25:3, 345-366.

De Vos, Christian (2015) "All roads lead to Rome: Implementation and Domestic Politics in Kenya and Uganda" in Christian De Vos, Sara Kendall and Carsten Stahn (eds.) Contested Justice. The Politics and Practice of International Criminal Court Interventions (Cambridge: Cambridge University Press).

Easterday, Jennifer (2015) "Behind the 'shadow' of the ICC: struggles over control of the conflict narrative in Colombia" in Christian De Vos, Sara Kendall and Carsten Stahn (eds.) Contested Justice. The Politics and Practice of International Criminal Court Interventions (Cambridge: Cambridge University Press).

Engle, Karen (2015) "Anti-impunity and the turn to criminal law in human rights", Cornell Law Review 100, 1069-1127.

Epstein, Charlotte (2012) "Stop telling us how to behave: Socialization or infantilization?", International Studies Perspectives 13:2, 135-145.

Fehl, Caroline (2004) "Explaining the International Criminal Court: A 'Practice Test' for Rationalist and Constructivist Approaches”, European Journal of International Relations 10:3, 357-394.

Fichtelberg, Aaron (2006) "Democratic Legitimacy and the international criminal court: a Liberal Defence" 4:4, 765-785.

García Iommi, Lucrecia (2019) "Whose Justice? The ICC Africa Problem", International Relations https://doi.org/10.1177/0047117819842294.

Garland, David (1990) Punishment and modern society: A study in social theory (Chicago, IL: University of Chicago Press).

Gevers, Christopher (2014) "International Criminal Law and Individualism: an African perspective" in Christine Schwöbel (ed.) Critical Approaches to International Criminal Law (New York: Routledge).

Gissel, Line Engbo (2018) "A Different Kind of Court: Africa's Support for the International Criminal Court, 1993-2003”, The European Journal of International Law 29:3, 725-748. 
Glasius, Marlies (2002) "Expertise in the Cause of Justice: Global Civil Society Influence on the Statute for an International Court" in Marlies Glasius, Mary Kaldor and Helmut Anheier (eds.), Global Civil Society (Oxford, UK: Oxford University Press), 137-168.

Glasius, Marlies (2005) The International Criminal Court: A Global Civil Society Achievement (London and New York: Routledge).

Gleditsch, Kristian and Michael Ward (2006) "Diffusion and the International Context of Democratization”, International Organization 60:4, 911-33.

Goodliffe, Jay and Darren Hawkins (2009) "A Funny Thing Happened on the Way to Rome: Explaining International Criminal Court Negotiations”, The Journal of Politics 71:3, 977-997.

Gonzalez Ocantos, Ezequiel (2018) "Communicative Entrepreneurs: The Case of the InterAmerican Court of Human Rights' Dialogue with National Judges", International Studies Quarterly 62:4, 737-750.

Gurowitz, Amy (1999) Mobilizing International Norms: Domestic Actors, Immigrants, and the State (Germany, Japan, Canada, Malaysia) Unpublished manuscript, Cornell University, Ithaca, N.Y.

Haddad, Heidi Nichols (2013) "After the norm cascade: NGO mission expansion and the Coalition for the International Criminal Court", Global Governance 19:2, 187-206.

Hillebrecht, Courtney and Scott Straus (2017) "Who Pursues the Perpetrators?: State Cooperation with the ICC”, Human Rights Quarterly 39:1, 162-188.

Hillebrecht, Courtney, Alexandra Huneeus and Sandra Borda (2018) "The Judicialization of Peace" Harvard International Law Journal 95: 2, 279- 330.

Holmes, John (1999) "The Principle of Complementarity" in Roy Lee (ed.) The International Criminal Court. The Making of the Rome Statute. Issues, Negotiations, Results. (The Hague: Kluwer Law International).

ICC website (2019) "Situations under investigation", $\underline{\text { https://www.icc- }}$ cpi.int/pages/situation.aspx

Katzenstein, Peter (1996) The culture of national security: Norms and identity in world politics. (New York: Columbia University Press).

Keohane, Robert (1984) After hegemony (Princeton, N.J.: Princeton University Press).

Koremenos, Barbara, Charles Lipson, and Duncan Snidal (2001) "The rational design of international institutions", International organization 55:4, 761-799. 
Kress, Claus (2006) "Versailles-Nuremberg-The Hague Germany and International Criminal Law", International Law 40, 15-39.

Lee, Joanne (2013) "Enough Rope: The Role of Minervian Actors in Establishing the International Criminal Court" in Yves Tiberghien (ed.), Leadership in Global Institution Building: Minerva's Rule (Basingstoke, UK: Palgrave Macmillan), 213-231.

Leonard, Eric (2005) The onset of global governance: International relations theory and the International Criminal Court (New York: Routledge).

Maqungo, Sivu (2000) "The establishment of the international criminal court: SADC's participation in the negotiations", African Security Review 9:1, 42-53.

Mills, Kurt (2012) “'Bashir is Dividing Us': Africa and the International Criminal Court”, Human Rights Quarterly 34:2, 439-445.

Mills, Kurt and Alan Bloomfield (2018) “African Resistance to the International Criminal Court: Halting the advance of the anti-impunity norm", Review of International Studies 44:1, 101-127.

Minow, Martha (1998) BetweenVengeance and Forgiveness: Facing History After Genocide and Mass Violence (Boston: Beacon Press).

Moradian, Davood (2006) Punishment Across Borders: Transnational Conceptions of Punishment; The Conception of Punishment in Classical Athens, Islam and International Criminal Justice. Dissertation, University of St. Andrews,

Moravcsik, Andrew (2000) "The origins of human rights regimes: Democratic delegation in postwar Europe", International Organization 54:2, 217-252.

Murphy, Jeffrei (1987) "Does Kant have a theory of punishment”, Columbia Law Review 87:3, 509-532.

Murphy, Jeffrie (2003) "Christianity and criminal punishment", Punishment \& Society 5:3, 261277.

Naqvi, Yasmin (2018) “Amnesties and the ICC', The Peace and Justice Initiative", available at: http://www.peaceandjusticeinitiative.org/implementation-resources/amnesties-and-the-icc

Neumann, Iver and Sieglinde Gstohl (2006) “Introduction. Lilliputians in Gulliver's World?" in Christine Ingebritsen (ed.), Small States in International Relations (Seattle/ Reykjavik: University of Washington Press/ University of Iceland Press).

Nouwen, Sarah (2013) Complementarity in the Line of Fire: the catalysing effect of the International Criminal Court in Uganda and Sudan (Cambridge: Cambridge University Press) 
Oola, Stephen (2015) "In the shadow of Kwoyelo's trial. The ICC and complementarity in Uganda" in Christian De Vos, Sara Kendall and Carsten Stahn (eds.) Contested Justice. The Politics and Practice of International Criminal Court Interventions (Cambridge: Cambridge University Press).

Panke, Diana (2012) "Small states in multilateral negotiations. What have we learned?", Cambridge Review of International Affairs 25:3, 387-398.

Pax Romana (1996) "Commentaries to the Draft Statute of the International Permanent Criminal Court." Available at: http://www.iccnow.org/documents/1PrepCmtCommentaryRomano.pdf

Pensky, Max (2008) "Amnesty on Trial: impunity, accountability, and the norms of international law", Ethics and Global Politics 1: 1-2: 1-40.

Risse-Kappen, Thomas (1995) Cooperation among democracies: The European influence on US foreign policy (Princeton, N.J.: Princeton University Press).

Robinson, Darryl (2003) "Serving the Interests of Justice: Amnesties, Truth Commissions and the International Criminal Court”, European Journal of Law 14:3, 481-505.

Robinson, Darryl (2013) "A cosmopolitan liberal account of international criminal law", Leiden Journal of International Law 26:1, 127-153.

Robinson, Patrick (2002) "The missing crimes". In The Rome Statute of the International Criminal Court: a Commentary, Antonio Casssese (ed.), 497-526 (New York: Oxford University Press).

Scharf, Michael (1999) "The Amnesty Exception to the Jurisdiction of the International Criminal Court", Cornell International Law Journal 32: 3, 507-527.

Simmons, Beth and Allison Danner (2010) "Credible Commitments and the International Criminal Court”, International Organization 64:2, 225-256.

Struett, Michael (2008) The Politics of Constructing the International Criminal Court. NGOs, Discourse, and Agency (New York: Palgrave MacMillan).

Tabak, Shana (2009) "Article 124, War Crimes, and the development of the Rome Statute", Georgetown Journal International Law 40: 1069-1099.

Tallgren, Immi (2015) "The voice of the international: Who is speaking?", Journal of International Criminal Justice 13:1, 135-155.

Tao, Jing (2015) "China's Socialization in the International Human Rights Regime: why did China reject the Rome Statute of the International Criminal Court?", Journal of Contemporary China 24:96, 1092-1110. 
TerraViva (1998) “High Noon” July $15^{\text {th }}$, https://www.legal-tools.org/doc/e749b5/pdf/

United Nations (1992) Summary of Records of $21^{\text {st }}$ Meeting, Sixth Commission, A/C.6/47/SR.21.

United Nations (1994) Sixth Committee $17^{\text {th }}$ meeting, A/C.6/49/SR.17.

United Nations (1995a) Sixth Committee, $26^{\text {th }}$ meeting, A/C.6/50/SR.26.

United Nations General Assembly (1995b) 50 ${ }^{\text {th }}$ Session. Sixth Committee. Summary Records of the $30^{\text {th }}$ Meeting, A/C.6/50/SR.30.

United Nations (1996) Press Release: "Role of Security Council in triggering prosecution discussed in Preparatory Committee for International Criminal Court", L/2776.

United Nations (1996) Press Release: "Balance of Investigative Authority and State Sovereignty Focus of Discussion in Preparatory Committee on Establishment of International Criminal Court", L/2795.

United Nations (1998) U.N. Diplomatic Conference of Plenipotentiaries on the Establishment of an International Criminal Court. Summary records of the plenary meetings and of the meetings of the Committee of the Whole. 15 June 1998-17 June 1998. Official Records: Volume II. A/CONF.183/.

United States Delegation (1997) "U.S. Delegation Paper on State Practice Regarding Amnesties and Pardons", Non-paper/WG.3/No.7 6 August 1997. Available at:

http://www.iccnow.org/documents/USDraftonAmnestiesPardons.pdf

Van Der Vyver, Johan (2003) "Civil society and the International Criminal Court, Journal of Human Rights”, 2:3, 425-439.

Vasiliev, Sergey (2017) 'Between International Criminal Justice and Injustice: Theorising Legitimacy,' in Nobuo Hayashi (editor) The Legitimacy and Effectiveness of International Criminal Tribunals (Cambridge: Cambridge University Press), 66-91.

Wendt, Alexander (1999) Social theory of international politics (Cambridge: Cambridge University Press).

Wenzel, Michael et al. (2008) "Retributive and Restorative Justice", Law \& Human Behavior 32, 375-389.

Wiener, Antje (2008) The Invisible Constitution of Politics (Cambridge, U.K.: Cambridge University Press). 
Wiener, Antje (2009) "Enacting meaning-in-use: qualitative research on norms and international relations", Review of International Studies 35:1, 175-193.

Wiener, Antje (2014) A Theory of Contestation (Heidelberg, Germany: Springer).

Wiener, Antje (2016) “Contested Norms in Inter-National Encounters: The 'Turbot War' as a Prelude to Fairer Fisheries Governance”, Politics and Governance 4:3, 20-36.

Wiener, Antje (2017a) "A Theory of Contestation- A Concise Summary of Its Arguments and Concepts", Polity 49:1, 109-125.

Wiener, Antje (2017b) “Agency of the governed in global international relations: access to norm validation" Third World Thematics: A TWQ Journal 2:5, 709-725.

Wiener, Antje and Uwe Puetter (2009) "The Quality of Norms is What Actors Make of It Critical-Constructivist Research on Norms", Journal of International Law and International Relations 5:1, 1-16.

Witte, John and Thomas Arthur (1993) "The Three Uses of the Law: A Protestant Source of the Purposes of Criminal Punishment?", Journal of Law and Religion 10:2, 433-465. 


\section{Appendix A}

\begin{tabular}{|c|c|}
\hline \multirow{2}{*}{$\begin{array}{l}\text { Entrepreneurs (LMG by } \\
\text { April } 1996 \text { signatories) }\end{array}$} & \multirow{3}{*}{$\begin{array}{l}\text { Supporters } \\
\text { (LMG by April } 1996 \\
\text { signatories) * }\end{array}$} \\
\hline & \\
\hline 1. Argentina & \\
\hline Australia & Lithuania \\
\hline Austria & Benin \\
\hline Belgium & Bosnia \\
\hline Canada & Malawi \\
\hline Chile & Brunei \\
\hline Italy & Bulgaria \\
\hline Croatia & Namibia \\
\hline Denmark & Burkina Faso \\
\hline 10. Egypt & Philippines \\
\hline 11. Finland & 10. Burundi \\
\hline 12. Germany & 11. Poland \\
\hline 13. Greece & 12. Republic of Congo \\
\hline 14. Guatemala & 13. Romania \\
\hline 15. Hungary & 14. Costa Rica \\
\hline 16. Ireland & 15. Senegal \\
\hline 17. Italy & 16. Czech Republic \\
\hline 18. Lesotho & 17. Sierra Leone \\
\hline 19. Netherlands & 18. Estonia \\
\hline 20. New Zealand & 19. Singapore \\
\hline 21. Norway & 20. Gabon \\
\hline 22. Slovakia & 21. Slovenia \\
\hline 23. South Africa & 22. Georgia \\
\hline 24. Portugal & 23. Solomon Islands \\
\hline 25. Sweden & 24. Ghana \\
\hline 26. Switzerland & 25. Spain \\
\hline 27. Trinidad and Tobago & 26. Jordan \\
\hline 28. Samoa & 27. Swaziland \\
\hline 29. Uruguay & 28. Republic of Korea \\
\hline 30. Venezuela & 29. United Kingdom \\
\hline & 30. Latvia \\
\hline & 31. Zambia \\
\hline
\end{tabular}

$\begin{array}{cll}\text { Accepting States (Signatories } & 46 . & \text { Paraguay } \\ \text { that were not part of the LMG) } & 47 . & \text { Panama } \\ \text { 1. Afghanistan } & 48 . & \text { Peru } \\ \text { 2. Albania } & 49 . & \text { Russia } \\ \text { 3. Algeria } & 50 . & \text { Syria } \\ \text { 4. Angola } & 51 . & \text { Tajikistan } \\ \text { 5. Armenia } & 52 . & \text { Tanzania } \\ \text { 6. Bangladesh } & 53 . & \text { Thailand } \\ \text { 7. Bahrain } & 54 . & \text { Tunisia } \\ \text { 8. Bolivia } & 55 . \text { Uzbekistan } \\ \text { 9. Botswana } & 56 . \text { Uganda } \\ \text { 10. Brazil } & 57 . \text { Ukraine } \\ \text { 11. Cameroon } & 58 . \text { United Arab Emirates } \\ \text { 12. CAR } & 59 . \text { Zimbabwe } \\ \text { 13. Chad } & \end{array}$

Countries that voted against Rome Statute

1. China

2. Cuba

3. El Salvador

4. Ethiopia

5. India

6. Indonesia

7. Iran

8. Iraq

9. Israel

10. Kazakhstan

11. Laos

12. Lebanon

13. Libya

14. Malaysia

15. Mauritania

16. Nepal

17. Nicaragua

18. Pakistan

19. Qatar

20. Rwanda

21. Saudi Arabia

22. Sri Lanka

23. Sudan

24. Togo

25. Turkey

26. United States

27. Vietnam

42. Mozambique

43. Niger

44. Nigeria

45. Oman

Source: Bassiouni (1999, 455 fn. 51).

*Notes: LMG states as of April 1996 were still members by June 1998 and should be considered part of the LMG at that time. 


\section{Appendix B}

\section{Predicted Response Support for the Rome Statute Crosstabulation}

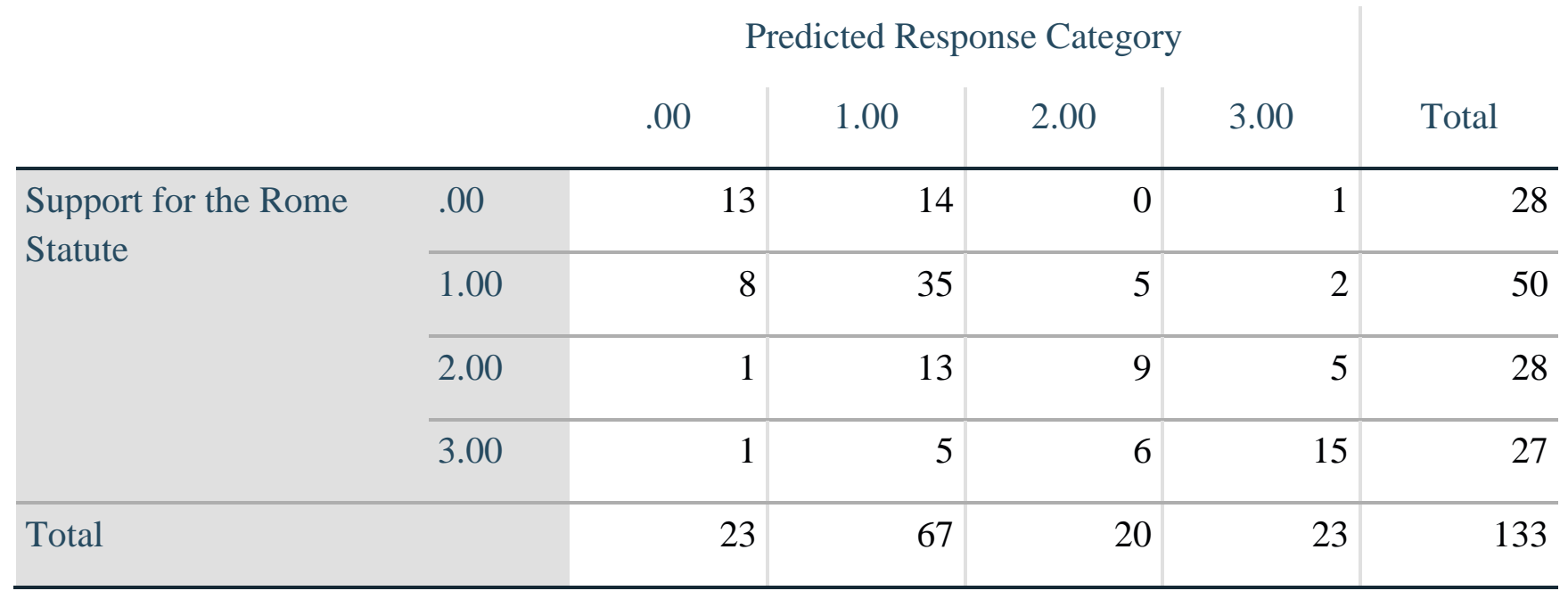




\section{Appendix C}

\section{Lrtest \\ (complete model against ideational factors only)}

LR chi2 $(13)=37.32$

Prob $>$ chi $2=0.0004$

\section{Test of Parallel Lines ${ }^{\mathrm{a}}$}

\begin{tabular}{lr|r|r|r} 
Model & $\begin{array}{c}-2 \text { Log } \\
\text { Likelihood }\end{array}$ & Chi-Square & df & \multicolumn{1}{c}{ Sig. } \\
\hline Null Hypothesis & 268.797 & & & \\
\hline General & $250.307^{\mathrm{b}}$ & $18.491^{\mathrm{c}}$ & 32 & .973 \\
\hline
\end{tabular}

The null hypothesis states that the location parameters (slope coefficients) are the same across response categories. ${ }^{a}$

a. Link function: Logit.

b. The log-likelihood value cannot be further increased after maximum number of step-halving.

c. The Chi-Square statistic is computed based on the log-likelihood value of the last iteration of the general model. Validity of the test is uncertain. 


\section{Appendix D}

\section{Regional Conferences}

\begin{tabular}{|c|c|c|}
\hline Year & Type & Location \\
\hline 1990 & Expert Conference & Italy (Sicily) \\
\hline 1993 & Expert Meeting & Vancouver \\
\hline 1995 & Expert Conference & Italy (Sicily) \\
\hline 1996 & Expert Conference & Italy (Sicily) \\
\hline 1996 & Conference & Turin \\
\hline 1996 & Press Conference & The Netherlands \\
\hline 1996 & Conference & Nigeria \\
\hline 1996 & International Conference & New York \\
\hline 1996 & Conference & Sierra Leone \\
\hline 1996 & Conference & India \\
\hline 1996 & Conference & Nepal \\
\hline 1996 & Seminar & Botswana \\
\hline 1996 & Conference & Bangladesh \\
\hline 1996 & Debate & Kenya \\
\hline 1996 & Conference & Iceland \\
\hline 1997 & International Conference & UK \\
\hline 1997 & Expert Conference & Italy (Sicily) \\
\hline 1997 & International Conference & Denmark \\
\hline 1997 & Symposium & Brussels \\
\hline 1997 & Regional Conference & South Africa \\
\hline 1997 & International Conference & Uruguay \\
\hline 1998 & Seminar & Norway \\
\hline 1998 & Seminar & Poland \\
\hline 1998 & Seminar & Russia \\
\hline 1998 & Conference & Switzerland \\
\hline 1998 & Seminar & Australia \\
\hline 1998 & International Conference & Austria \\
\hline 1998 & Workshop & Mexico \\
\hline 1998 & Conference & Guatemala \\
\hline 1998 & International Conference & Trinidad and Tobago \\
\hline 1998 & Forum & Santiago \\
\hline 1998 & Regional Conference & Senegal \\
\hline 1998 & Press Conference & Spain \\
\hline
\end{tabular}

Sources: Glasius, 2005: 148-9 and CICC website 